\title{
Comparative effects of water-column nitrate enrichment on eelgrass Zostera marina, shoalgrass Halodule wrightii, and widgeongrass Ruppia maritima
}

\author{
JoAnn M. Burkholder, Howard B. Glasgow Jr, Jacob E. Cooke \\ Department of Botany, Box 7612, North Carolina State University, Raleigh, North Carolina 27695-7612, USA
}

\begin{abstract}
In an experimental mesocosm system during late summer-fall, we examined shoot production by eelgrass Zostera marina without nitrate additions (generally with ambient water-column concentrations $<2 \mu \mathrm{M} \mathrm{NO}_{3}-\mathrm{N}$ ) versus production by eelgrass that previously had been exposed to low nitrate enrichment (pulsed additions of $5 \mu \mathrm{M} \mathrm{NO}_{3}{ }^{-}-\mathrm{N} \mathrm{d}^{-1}$ to the water for $12 \mathrm{wk}$ during an unusually cool spring season). During late summer-fall, the previously enriched plants were subjected to higher nitrate loading $\left(10 \mu \mathrm{M} \mathrm{NO}_{3}^{-}-\mathrm{N} \mathrm{d}^{-1}\right.$ for $\left.14 \mathrm{wk}\right)$, while control plants were maintained without nitrate additions as in spring. We also compared shoot production in fall by recent field transplants of $Z$. marina, Halodule wrightii, and Ruppia marituma with and without additions of $10 \mu \mathrm{M}$ water-column $\mathrm{NO}_{3}{ }^{-}-\mathrm{N} \mathrm{d}^{-1}$. Low water exchange $\left(10 \% \mathrm{~d}^{-1}\right)$ was used to simulate conditions in sheltered embayments or lagoons, and light reduction from high tide was simulated by covering the mesocosms with neutraldensity screens that reduced incident light by $30 \%$ for $3 \mathrm{~h} \mathrm{~d}^{-1}$ on a rotating schedule. Shoot production by both enriched and unenriched $Z$. marina was comparable during the spring low-level $\mathrm{NO}_{3}^{-}-\mathrm{N}$ exposure. However, eelgrass enriched with nitrate in both spring and fall attained significantly lower shoot production than control plants without enrichment. This decrease, unrelated to light reduction from algal growth, suggests a direct adverse effect of long-term water-column nitrate exposure on $Z$. marina. The more recent transplants of eelgrass without prior enrichment history also showed a trend for decreased lateral growth under moderately elevated nitrate. In contrast, $H$. wrightii was slightly stimulated and $R$. maritima was highly stimulated by water-column nitrate relative to growth of controls. By the end of the fall experiment, Z. marina $\left( \pm \mathrm{NO}_{3}^{-}-\mathrm{N}\right), H$. wrightii $\left( \pm \mathrm{NO}_{3}^{-}-\mathrm{N}\right)$, and unenriched $R$. maritima had increased shoot densities by $\leq 50 \%$, whereas nitrate-enriched $R$. maritima increased shoot production by $>300 \%$. The data indicate that $H$. wrightii or $R$. maritima could be established successfully by transplanting efforts as a management strategy in nitrate-enriched waters where eelgrass meadows have disappeared. Unlike $Z$. marina, these species apparently have developed physiological mechanisms to more effectively control nitrate uptake and metabolism.
\end{abstract}

KEY WORDS: Eutrophication - Macrophytes - Nitrate $\cdot$ Seagrass $\cdot$ Zostera marina

\section{INTRODUCTION}

The high productivity, habitat value, substrate stabilization, and other beneficial effects of seagrass meadows prompted ecologists McRoy \& McMillan (1977) to write, 'We know enough to understand in general what we would lose if catastrophe took seagrass ecosystems from the world oceans. We would lose options. More than ever, that is a loss beyond affording.' Within the past few decades, catastrophic losses of seagrass mead- ows have been correlated with nutrient loading from cultural eutrophication (Borum 1985, Twilley et al. 1985, Orth et al. 1986). Eutrophication effects on seagrasses are most severe in sheltered habitats with reduced tidal flushing, where nutrient loadings are both concentrated and frequent, and where temperatures fluctuate more widely than in areas with greater water exchange (Stevenson 1988, Maier \& Pregnall 1990).

Among the 3 most commonly considered inorganic nutrient forms contributed in anthropogenic inputs, 
phosphate and ammonia readily adsorb to particulate matter and, as a result, are less available to plants for uptake than the abundant, highly soluble, and readily transported nitrate (Alberts \& Moldenhauer 1981, Grobbelaär 1983, Froelich 1988, Simon 1989). In largescale experimental mesocosms under warm spring conditions and simulated reduced tidal flushing, we recently determined that water-column nitrate enrichment can cause death to eelgrass Zostera marina L. as a direct physiological effect unrelated to algal light attenuation (Burkholder et al. 1992). The apparent lack of an inhibition mechanism for sustained nitrate uptake by eelgrass leaf tissue (Roth \& Pregnall 1988) was hypothesized to eventually cause internal imbalances in supply ratios of other critically needed nutrients such as carbon or phosphorus (Burkholder et al. 1992), perhaps from the need to shunt carbon skeletons for amino acid synthesis in order to prevent internal accumulation of toxic products such as ammonia (Turpin 1991).

One surprising aspect of our previous results was that pulsed daily additions of even low levels of enrichment ( 3.5 to $7.0 \mu \mathrm{M} \mathrm{NO}_{3}{ }^{-}-\mathrm{N} \mathrm{d}^{-1}$ for $8 \mathrm{wk}$ ) adversely affected eelgrass. The permissible level of watercolumn nitrate that enables long-term survival of Zostera marina would be expected to change depending on interactions with other variables such as temperature, light, past history of exposure to nitrate, duration of exposure to elevated nitrate, and age/general physiological condition of the plants. Z. marina likely evolved in nutrient-poor waters, and sustained nitrate uptake under temporary enrichment may have developed as a competitive strategy that was once highly advantageous. As coastal waters have become progressively more eutrophic, however (Magnien et al. 1992, Miller 1992), this trait might instead have enabled less nitrate-sensitive macrophytes to establish and become dominant in nitrate-rich waters.

The 2 objectives of the present research were to examine fall growth of eelgrass with/without a prehistory of exposure to water-column nitrate enrichment, and to compare shoot production by Zostera marina and 2 co-inhabitant angiosperms, shoalgrass Halodule wrightii Ascher and widgeongrass Ruppia maritima L. under elevated water-column nitrate. Although they generally are considered to be of lower habitat value than $Z$. marina, these submersed macrophytes also provide habitat and food for commercially important finfish, shellfish and waterfowl (Kikuchi \& Peres 1977, Thayer et al. 1979, Thayer et al. 1984). H. wrightii and $R$. maritima are of potential interest in re-establishing submersed aquatic vegetation where loss of $Z$. marina has been correlated with nutrient enrichment from coastal development (Orth et al. 1986).

\section{MATERIALS AND METHODS}

Study area. This research was conducted in North Carolina, USA, representing the southernmost extension for Zostera marina and the northernmost extension for Halodule wrightii on the western Atlantic Coast (Thayer et al. 1984). In this area eelgrass grows stunted from high-temperature stress (Den Hartog 1970); its maximum shoot length averages only ca $40 \mathrm{~cm}$ (Thayer et al. 1984). Shallow bay waters typically reach $33^{\circ} \mathrm{C}$ from late spring through early autumn (Thayer et al. 1984, NOAA 1993). Temperatures above $30^{\circ} \mathrm{C}$ have been shown to be detrimental to eelgrass by increasing respiration and impairing enzyme activities (Lambers 1985, Marsh et al. 1986, Zimmerman et al. 1989). Agriculture, industry, and accelerated coastal development in North Carolina have been associated with increased nutrient loading (Jacobs \& Gilliam 1985, Stanley 1988), and loss of eelgrass habitat in upper embayments has been reported anecdotally in the absence of long-term vegetation maps (Ferguson et al. 1988, Mather 1988).

Eelgrass mesocosm system: physical/chemical characteristics. The experimental seagrass mesocosm system is located outdoors on the north shore of Beaufort Inlet at the Southeast Laboratory of the National Marine Fisheries Service (NMFS) on Pivers Island. The system consists of fiberglass mesocosms coated with non-toxic white gelcoat resin. Each mesocosm is $2 \mathrm{~m}$ in diameter $\times 1 \mathrm{~m}$ in height, with a $60 \mathrm{~cm}$ working depth that was established by creating a raised bottom to accommodate our small plants (mean length $40 \mathrm{~cm}$ ) while reducing wall shading effects. Water depth and sediment thickness during experiments were $0.5 \mathrm{~m}$ and $12 \mathrm{~cm}$, respectively. Running seawater was pumped in from a $4 \mathrm{~m}$ depth (high tide) at a location upstream from the dock area at NMFS. The sediment consisted of clean dredge sand and salt marsh mud in a 3:1 ratio by volume. To minimize heterogeneity among mesocosms, approximately $8 \mathrm{t}$ of sediment were homogenized with a cement mixer and distributed equally to a depth of ca $15 \mathrm{~cm}$. For 11 mo before beginning the experiments, the sediment was maintained with eelgrass shoots transplanted from an unenriched field site (Middle Marsh near Beaufort; initially ca 500 plants $\mathrm{m}^{-2}$ ) under $\leq 25 \%$ water exchange $\mathrm{d}^{-1}$. After 6 mo the sediment had become well colonized by diverse communities of algae and invertebrates (as in Burkholder et al. 1992)

A chiller system ( 3 custom-designed, $4.5 \mathrm{t}$ condensing units, each capable of a maximum of 60000 BTU h $^{-1}$ cooling capacity) was used to maintain baywater temperatures and mixing, with current velocities set at 5 to $8 \mathrm{~cm} \mathrm{~s}^{-1}$. Within the chillers, electronically controlled thermal expansion valves regulated freon coolant to 
each titanium heat exchanger, and provided independent temperature control for each mesocosm. Ambient temperature and salinity of the baywater were 9 to $28^{\circ} \mathrm{C}$ and 26 to $36 \%$, respectively, during spring and late summer-fall 1992. Diurnal temperature extremes of the shallow baywater and the mesocosms were at $\leq 6^{\circ} \mathrm{C}$ during both spring and late summer-fall. Throughout the experiments the mesocosms were maintained at $\pm 2{ }^{\circ} \mathrm{C}$ of ambient baywater temperatures $\left(<27^{\circ} \mathrm{C}\right.$ on warmest days). By comparison, ambient bay temperatures in shallow coastal waters typically reach 30 to $33^{\circ} \mathrm{C}$ from late spring through early autumn (Thayer et al. 1984, NOAA 1993). Light reduction from high tide was simulated using neutral density shades that reduced photosynthetically active radiation by about $30 \%$ while still maintaining light above saturation for eelgrass photosynthesis ( $>350 \mu \mathrm{Ein} \mathrm{m}^{-2} \mathrm{~s}^{-1}$; Dennison \& Alberte 1982, Dennison 1987).

During experiments (spring: 26 March to 17 June 1992; late summer-fall: 30 August to 6 December 1992), nitrate was added daily between 08:00 and 10:00 $\mathrm{h}$ when high uptake was expected (Morris 1974, Turpin 1991), whereas low water exchange $\left(10 \% \mathrm{~d}^{-1}\right.$, simulating conditions in poorly flushed coastal embayments and lagoons) was completed between 16:00 and 18:00 h during late afternoon. Each mesocosm was independent of the others in plumbing of intake and outflow lines, so that there was no treatment cross-contamination. Nitrate-contaminated water was gravity-fed to a small salt marsh ca $200 \mathrm{~m}$ from the mesocosm water intake site, for effective treatment and to prevent contamination of mesocosms during water exchange.

Preparation and experimental design. In the $11 \mathrm{mo}$ system acclimation period following sediment exchange, eelgrass shoots that were transplanted into the experimental system during May 1991 (from the same unenriched field site at Middle Marsh) had attained dense growth of $>1500$ shoots $\mathrm{m}^{-2}$ in most mesocosms, with thick masses of roots and rhizomes which were difficult to dislodge. To reset the system with homogeneous populations of eelgrass, algae and macroinvertebrates prior to the spring 1992 nitrate experiment, we removed all eelgrass plants (including attached belowground tissue) from the mesocosms, separated them by mesocosm number, and floated them in running seawater. Mesocosm walls were scraped clean of most macroalgae and repeatedly drained to flush residual algal suspensions. The sediments and walls were also vacuumed. Plants were cleaned of most epiphytes, sorted into loose bundles of 5 to 8 shoots, and maintained in flow-through seawater at ambient baywater temperature $\left(14^{\circ} \mathrm{C}\right)$ until they were replanted (within $3 \mathrm{~d}$ ). The planting procedure normalized any long-term, enclosure-specific effects among the mesocosm communities. Shoots were transplanted to attain initial densities of $\geq 850$ plants $\mathrm{m}^{-2}$, and were allowed to acclimate for 3 wk before beginning nitrate additions in treated mesocosms. To help control herbivore densities and to include a higher trophic level, we added 5 small Atlantic croaker Micropogonias undulatus $\mathrm{L}$. to each mesocosm. Occasional dead fish were removed and replaced with live fish throughout the experiments.

During the spring season of maximal eelgrass growth (Thayer et al. 1984) and maximal sensitivity to water-column nitrate (Burkholder et al. 1992), we compared control eelgrass transplants (ambient nitrate generally $<2 \mu \mathrm{M} \mathrm{NO}_{3}-\mathrm{N}$ ) to transplants under 'low' nitrate enrichment at ambient baywater temperatures (pulsed additions of $5 \mu \mathrm{M} \mathrm{NO}_{3}{ }^{-} \mathrm{N} \mathrm{d}^{-1}$ for a total loading of ca $3.06 \mathrm{~g} \mathrm{~m}^{-2}$ for $12 \mathrm{wk}$ or, if extended, the equivalent of $13.3 \mathrm{~g} \mathrm{NO}_{3}^{-}-\mathrm{N} \mathrm{m}^{-2} \mathrm{yr}^{-1}$ ). The late summer-fall experiment compared macrophyte species response to 'moderate' nitrate enrichment as $10 \mu \mathrm{M}$ $\mathrm{NO}_{3}{ }^{-} \mathrm{N} \mathrm{d}^{-1}$, a level considered to adversely affect eelgrass growth in autumn based on previous data (Burkholder et al. 1992; total loading of ca $7.13 \mathrm{~g} \mathrm{~m}^{-2}$ for $14 \mathrm{wk}$ or, if extended, the equivalent of $26.6 \mathrm{~g} \mathrm{NO}_{3}{ }^{-} \mathrm{N}$ $\mathrm{m}^{-2} \mathrm{yr}^{-1}$ ). The selected loadings were within the range reported for estuaries under cultural eutrophication [generally $\geq 10 \mathrm{~g}$ dissolved inorganic nitrogen (DIN) $\mathrm{m}^{-2} \mathrm{yr}^{-1}$; e.g. Valiela \& Costa 1988, Magnien et al. 1992, Monbet 1992, Nienhuis 1992]. The fall season coincided with a second, less productive period for cold-optimal Zostera marina within an annual cycle (Penhale 1977), and with the active growing season for Halodule wrightii and Ruppia maritima. All 3 species are perennials but $H$. wrightii and $R$. maritima are warm-optimal, with growth beginning in late spring and extending into late fall (Muenscher 1964, Thayer et al. 1984). Hence, the late summer-fall experimental period encompassed seasonal growth periods for the 3 species, and simulated the natural progression of seasonal activity by each macrophyte.

Mesocosms were randomly selected as controls or Nenriched for the spring experiment, with each mesocosm consistently maintained as either a control or an $\mathrm{N}$-enriched replicate during both spring and late summer-fall (Fig. 1). At $30 \mathrm{~min}$ after adding nitrate to enriched enclosures in the spring low $\mathrm{N}$ treatment, $\mathrm{NO}_{3}{ }^{-}$- $\mathrm{N}$ averaged $5.2 \pm 1.3 \mu \mathrm{M}$, versus background concentrations of $2.5 \pm 0.5 \mu \mathrm{M} \mathrm{NO}_{3}{ }^{-}-\mathrm{N}$ measured $24 \mathrm{~h}$ later, prior to the next pulsed nitrate addition (comparable to or slightly higher than ambient; $\mathrm{n}=3$ trials at monthly intervals). Thus, at the low $\mathrm{N}$ additions used in spring, nitrate did not accumulate in the water column of enriched mesocosms.

For more than $3 \mathrm{wk}$ after the spring experiment, all mesocosms were maintained in running seawater, and 


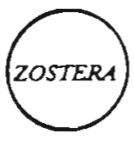

C-1

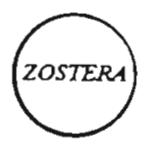

C-2

CONIROLS

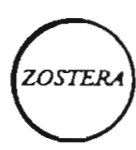

C-3

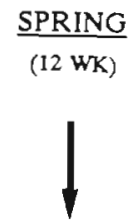

EXPERIMENT ENDED FLUSHED WTIH RUNNING

SEAWATER FOR 12 WK

I

PLANTS REMOVED;

MESOCOSMS RESET

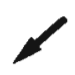

\section{MID-SUMMER}

(S DAYS)
PLANTS CLFANED, SORTED \& BUNDLED.

\section{PLANT ALLOCATION}

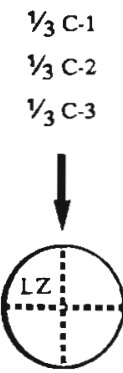

C-1

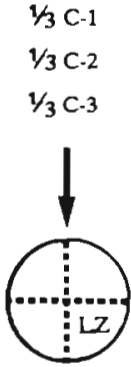

C-2
$1 / 3 \mathrm{C}-1$

$1 / 3 \mathrm{C}-2$

$1 / 3 \mathrm{C}-3$

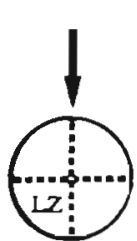

C-3
$\mathrm{N}-2$
$\mathrm{N}-3$

N-1

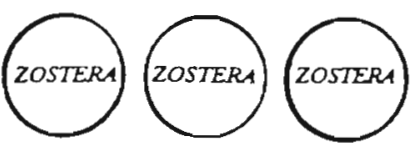

LOW N TREATMENT PLANT ALLOCATION:

\section{PLANTS CLEANED, SORTED \& BUNDLED.}

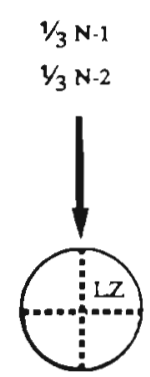

N-1
$1 / 3 \mathrm{~N}-1$

$1 / 3 \mathrm{~N}-2 \quad 1 / 3 \mathrm{~N}-2$
COLLECTED, CLEANED, BUNDLED AND PLANTED FRESH FIELD TRANS PLANTS OF ZOSTERA, HALODULE RUPPLA (S DAYS; ACCLMATED 6 WK) I

1 CONTROL AND 1 N-ENRICHED REPLCATE LOST (FUNGAL ATTACK)
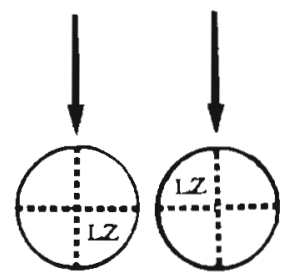

$\mathrm{N}-2$

N-3

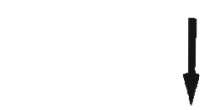

\section{LATE SUMMER - FALL}

(14 WK)
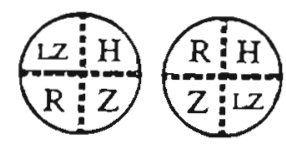

C-1

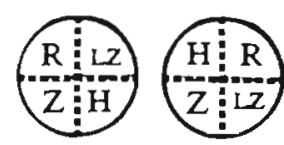

N-1

$\mathrm{N}-2$

MOD N ENRICHMENT

Fig. 1. Experimental design, spring-fall 1992. The spring experiment included 3 control $(\mathrm{C}-1, \mathrm{C}-2$ and $\mathrm{C}-3$; ambient nitrate at $<1.5 \mu \mathrm{M}$ ) and 3 low $\mathrm{N}$-enriched mesocosms (N-1, N-2 and N-3; $5 \mu \mathrm{M} \mathrm{NO}_{3}{ }^{-} \mathrm{N}_{\text {added }}{ }^{-1}$, or sufficient nitrate to effect a water-column concentration of $60 \mu \mathrm{g} \mathrm{l}^{-1}$ ). After the spring experiment, $\mathrm{N}$-enriched plants were collected and segregated by mesocosm. While mesocosms were reset (similar protocol as before the spring experiment), plants were cleaned and separated into 3 equal subgroupings. In the $\mathrm{N}$-enriched mesocosms, $1 / 4$ of the surface area was replanted with $50 \%$ as plants from $\mathrm{N}-1$ and $50 \%$ as plants from $\mathrm{N}-2$ ! = N-enriched LZ, or LTMA (long-term mesocosm-acclimated) Zostera manna for the late summer-fall experiment]. Plants from $\mathrm{N}$-3 were discarded because they had encountered low-light stress during spring (potentially confounded by crab disturbance and higher macroalgal growth) as well as nitrate enrichment. A similar process was followed for plants collected from/replanted into C-1, C-2 and C-3 (= control LZ, or LTMA Z. marina). During the same period, Z. marina, Halodule wrightii and Ruppia maritima (Z, $\mathrm{H}$ and $\mathrm{R}$ respectively) were freshly transplanted into the system from unenriched field habitat. A fungal attack occurred in 1 control and 1 enriched mesocosm between experiments, and these mesocosms were omitted as fall replicates 
the $\mathrm{N}$-treated mesocosms received no further nitrate additions. Plants were then collected and replanted as 'long-term, mesocosm-acclimated' (LTMA) eelgrass, following the procedure outlined in Fig. 1. Hence, these LTMA plants were used in both the spring and late summer-fall experiments. To compare macrophyte species response to water-column nitrate. Zostera marina, Halodule wrightii and Ruppia maritima also were freshly transplanted into the mesocosms from the same unenriched field site where the LTMA eelgrass had been collected. Each plant type occupied 1 delineated, randomly selected quarter of each mesocosm (Fig. 1). From 12 to 16 July these plants were collected, held in shallow tanks of running seawater, cleaned of most epiphytes and animals, bundled, and transplanted following procedures in Burkholder et al. (1992). Because eelgrass is larger than the other 2 species, Z. marina, $H$. wrightii and $R$. maritima were planted at approximate densities of 800,1200 and 1200 shoots $\mathrm{m}^{-2}$ respectively. Plants were acclimated in the mesocosms for 6 wk (water temperatures $\leq 31^{\circ} \mathrm{C}$ ) prior to initiating the late summer-fall experiment. During the first $2 \mathrm{wk}$ of that time, the mesocosms were flushed with running seawater from the bay ( 3 full exchanges $\mathrm{h}^{-1}$ ); for the remaining $4 \mathrm{wk}$ water exchange was imposed at $10 \% \mathrm{~d}^{-1}$.

In the late summer-fall experiment with moderate $\mathrm{N}$ additions, nitrate accumulated in the water column of enriched enclosures. At ca 30 min after treatment, nitrate averaged $12.0 \pm 1.5 \mu \mathrm{M} \mathrm{NO}_{3}{ }^{-}-\mathrm{N}$ versus concentrations of $6.3 \pm 4.5 \mu \mathrm{M} \mathrm{NO}_{3}{ }^{-} \mathrm{N}$ measured $24 \mathrm{~h}$ later prior to the next pulsed nitrate addition ( $n=4$ trials at biweekly intervals). Despite measurable nitrate accumulation, plant uptake and net export via water exchange maintained the mean and median seasonal DIN concentrations $\left(\mathrm{NO}_{3}{ }^{-}-\mathrm{N}+\mathrm{NH}_{4}{ }^{+}-\mathrm{N}\right.$ ) at $7.6 \mu \mathrm{M}$ (ca $0.11 \mathrm{mg}$ $\mathrm{1}^{-1}$ ) and $4.0 \mu \mathrm{M}$ (ca $0.06 \mathrm{mg} \mathrm{l}^{-1}$ ), respectively, over the 14 wk experiment, well below the median seasonal upper limit of $<0.15 \mathrm{mg} \mathrm{l}^{-1}$ identified by Batiuk et al. (1992) for protection of eelgrass in the lower Chesapeake Bay. Our targeted concentration of $10 \mu \mathrm{M}$ $\mathrm{NO}_{3}{ }^{-}-\mathrm{N}$ corresponded, in fact, to the maximal DIN concentration that has been established to protect eelgrass in the lower Chesapeake (Dennison et al. 1993).

Physical, chemical and community variables. Environmental variables that were measured routinely included temperature, salinity, photosynthetically active radiation (PAR), and water-column nitrate $\left(\mathrm{NO}_{3}{ }^{-}-\mathrm{N}\right)$, ammonium $\left(\mathrm{NH}_{4}{ }^{+}-\mathrm{N}\right)$, and total phosphorus (TP). Temperature was monitored daily by an automated digitized system that consisted of 12 Johnson model A350 electronic temperature control modules, used in conjunction with Johnson control model SET189A-600 temperature sensors that were mounted inside the mesocosms within immersion wells
(WEL11A-601R). Salinity was measured daily with a Reichert refractometer. PAR in the upper eelgrass canopy was recorded daily using a LiCor data logger (model 1000) connected to a submersible $4 \pi$ PAR quantum sensor (model LI-193SA). Samples for nutrient analyses were collected in duplicate from each mesocosm weekly during the early morning prior to addition of nitrate in treatments. Nitrate was determined on a Technicon autoanalyzer (model II) following the copper-cadmium reduction procedure of Parsons et al. (1985). Ammonium was measured with the Solórzano method (Parsons et al. 1985) using modifications of Burkholder \& Sheath (1985) for immediate preservation with phenol. TP was analyzed after acid persulfate digestion (Parsons et al. 1985).

Macroalgal abundance was estimated from harvests of three $0.1 \mathrm{~m}^{2}$ quadrats haphazardly positioned among Zostera marina in spring. During the late summer-fall experiment, 1 quadrat was haphazardly placed among growth of each of the 3 macrophyte species. In both experiments, the 3 quadrats and collections of wall growth were combined to obtain an estimate of macroalgal abundance for each mesocosm on the basis of surface area. Macroalgal taxa were separated, cleaned, and oven-dried at $60^{\circ} \mathrm{C}$. Periodic checks indicated that phytoplankton abundances were low $\left(<400\right.$ cells $\mathrm{ml}^{-1}$ ) throughout both experiments. Based on monthly estimates as in Burkholder et al. (1992), the biomass of microalgal epiphytes was negligible \pm nitrate enrichment, in comparison to that of floating and benthic macroalgae. Herbivory can control algal biomass seasonally in some seagrass habitats (Orth \& van Montfrans 1984, Neckles 1993, Williams \& Ruckelshaus 1993), and may indirectly influence $Z$. marina survival under nitrate enrichment. Hence, on 3 dates (initial, mid-point, and final) macro-invertebrate algal herbivores were quantified from 3 cores $4 \mathrm{~cm}$ diameteri that were collected to include 1 or more macrophyte shoots.

Macrophyte variables. Aboveground eelgrass productivity during spring was measured by the leaf puncture method of Zieman \& Wetzel (1980). Shoots were marked at $3 \mathrm{wk}$ intervals, and randomly selected subsets of 8 to 10 marked plants (or tags from dead plants) were collected weekly. This method was flawed since only shoots that were sufficiently large and robust to enable marking were selected; hence, the data overestimated mean growth and more closely approximated maximum estimates. Leaf growth measurements were omitted from the late summer-fall experiment. A more reliable indicator of plant response was obtained in both experiments by considering net shoot production ('lateral' growth), a population-level index (change in shoot number $=$ shoots present initially + shoots produced - dead shoots). 
Change in shoot density of the 4 plant categories (LTMA Zostera marina and recent field transplants of Z. marina, Halodule wrightii and Ruppia maritima) from each mesocosm over the experiment was determined by quantifying the total shoots within a marked $0.1 \mathrm{~m}^{2}$ quadrat.

Eelgrass and other angiosperms are known to decrease production of anti-microbial phenolics in $\mathrm{N}_{i-}$ enriched, light-replete conditions (Bazzaz et al. 1987. Buchsbaum et al. 1990). To assess whether watercolumn nitrate enrichment affected seagrass susceptibility to pathogenic organisms, the proportion of aboveground Zostera marina tissue (percentage of brown and blackened areas) affected by the opportunistic slime-mold-like pathogen Labyrinthula zosterae (Muehlstein et al. 1991) was estimated from plants harvested for growth measurements at 7 to $9 \mathrm{~d}$ intervals during spring, and in the first and last 2 wk of the late summer-fall experiment. On 3 dates in late summer-fall $(3,10$ and $14 \mathrm{wk})$, we also used light microscopy (100 to $600 \times$, Olympus BHS microscope) to compare the structural integrity of meristem crosssections from control versus $\mathrm{N}$-enriched eelgrass shoots. For these comparisons, fresh plant material from 6 plants per mesocosm was preserved in 50\% ethanol or in 5\% gluteraldehyde-seawater (Moffler \& Durako 1984 ; prefiltered with $0.8 \mu \mathrm{m}$ pore size Millipore filters), sectioned by hand (sterile technique within a laminar flow hood; tissue section thickness $10 \mu \mathrm{m}$ ), and paraffin-embedded. Fungal colonization was checked after staining tissue with aniline blue (Schneider 1981).

Above- and belowground tissue content of carbon, nitrogen and phosphorus was determined for Zostera marina at the beginning, mid-point and end of both the spring and late summer-fall experiments. Tissue C, N and $\mathrm{P}$ were also measured for $Z$. marina, Halodule wrightii and Ruppia maritima near the end of the late summer-fall experiment ( $11 \mathrm{wk}$ ). For $Z$. marina, 12 to 15 plants were collected from each mesocosm, whereas sufficient material of the 2 smaller species was collected to obtain $250 \mathrm{mg}$ of dried tissue for above- versus belowground analyses (ca 50 shoots per species). Whole plants (with leaves, rhizomes, and roots) were harvested between 10:00 and 13:00 h, carefully cleaned of algae and sediment in running seawater ( 2 to $3 \mathrm{~min}$ ), and frozen on dry ice for transport to the laboratory. They were held at $-70^{\circ} \mathrm{C}$ prior to separation of aboveground from belowground tissue. The tissue was thawed, ovendried at $60^{\circ} \mathrm{C}$ for $12 \mathrm{~h}$, finely ground, and analyzed by the Department of Forestry and the Analytical Laboratory in the Department of Soil Science at North Carolina State University.

Two tissue components, total protein content and total acid-soluble carbohydrates, were measured sepa- rately in above- and belowground tissue of Zostera marina near the end of the late summer-fall experiment (December, Week 12). Plants were harvested between 15:00 and 18:00 h, cleaned of epiphytes and sediment in running seawater, and transported to the laboratory in darkness on ice. The 3 youngest leaves and the living rhizomes (with beige-colored interior) and roots were used in the tissue analyses. For each mesocosm total protein was determined from a pooled sample of 3 randomly selected plants, following a modification of the Coomassie brilliant blue procedure (Dawes \& Kenworthy 1990). Acid-soluble or dissolved carbohydrates (including simple sugars, oligosaccharides, polysaccharides, and derivatives having a free or potentially free radical group) were measured following Dawes \& Kenworthy (1990).

On similar tissue, the activity of the primary enzyme involved in nitrate uptake, nitrate reductase (NRase), was assayed from Zostera marina after $3 \mathrm{wk}$ in both experiments, and also after $14 \mathrm{wk}$ in late summer-fall. From each mesocosm 6 plants were harvested cleaned, and transported to the laboratory, and NRase was assayed using the technique of Roth \& Pregnall (1988). The activity of a key enzyme involved in $N_{i}$ assimilation, glutamine synthetase (GS), was also assayed from $Z$. marina after 3 and $14 \mathrm{wk}$ in late summer-fall, following the procedure of Pregnall et al. (1987).

Statistical analyses. Separate data analyses were completed for the 2 seasonal experiments. Correlation analysis was performed initially by date to examine relationships between eelgrass aboveground growth (spring), macroalgal abundances, PAR, temperature, lag-effect temperature, and salinity (SAS Institute, Inc. 1987). Treatments were compared using the Student's t-test (Gill 1978). The (LTMA) Zostera marina plants used in the spring-fall manipulation had been maintained in the mesocosms for longer duration than plants included in the 3 -species comparison during late summer-fall. Hence, direct statistical comparison of the effects of water-column nitrate on LTMA $Z$. marina and the recent field transplants of $Z$. marina was not possible, although inferences were formed from trends in the data.

\section{RESULTS}

\section{Zostera marina communities and low nitrate exposure during spring}

The spring season was the third coldest in $50 \mathrm{yr}$, with baywater temperatures $4^{\circ} \mathrm{C}$ lower than average (19 yr weekly means; NOAA 1993). With exception of 1 date, mean water temperatures remained at $<25^{\circ} \mathrm{C}$ until 
mid-June (Fig. 2). Salinity was constant ( $>30 \%$ ) except for $8 \mathrm{~d}$ near the end of the experiment when high precipitation held salinity below $30 \%$ (Fig. 2). On each sampling date water temperatures varied by $\leq 2^{\circ} \mathrm{C}$ among all mesocosms, and salinities varied by $<3 \%$. Light (PAR) was comparable among the mesocosms except for a 3 wk period (Fig. 2) when a blue crab (Callinectes sapidus Rathbun) stirred the sediments in $\mathrm{N}$-enriched replicate $3(\mathrm{~N}-3)$ prior to its capture and removal.

As expected, water-column nutrient concentrations in control and nitrate-enriched mesocosms were comparable throughout the spring experiment. Mean $\mathrm{NO}_{3}{ }^{-}-\mathrm{N}$ levels in controls remained at $2 \mu \mathrm{M}$ or less except for increases up to ca $7 \mu \mathrm{M}$ during precipitation events (Fig. 3). The onset of warmer conditions toward the end of the spring experiment was associated with qualitatively higher mean levels of $\mathrm{NH}_{4}{ }^{+}-\mathrm{N}$ and TP in the enriched treatment, but concentrations of both nutrients did not differ significantly from those in controls (Fig. 3).
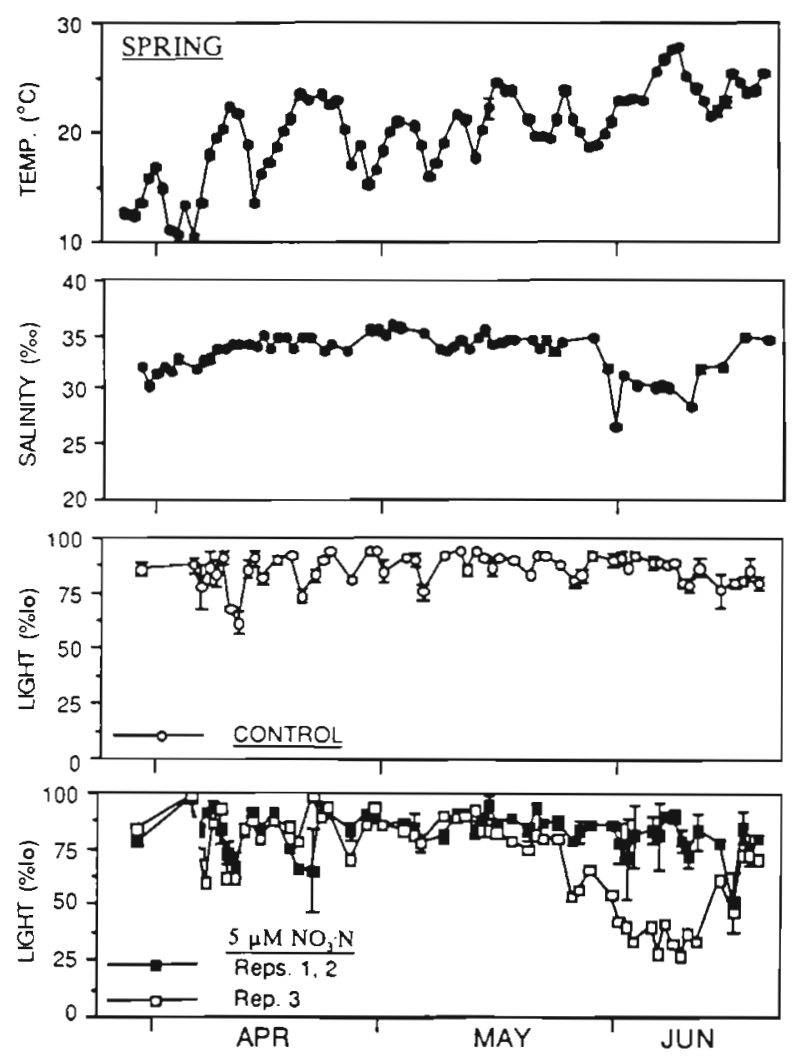

Fig. 2. Temperature, salinity and light (as the percent of total PAR just below the water surface) at the base of the eelgrass canopy during the spring 1992 experiment (means $\pm 1 \mathrm{SE}$ ), considering control and $5 \mu \mathrm{M} \mathrm{NO}_{3}{ }^{-}-\mathrm{N}$-enriched mesocosms collectively for temperature and salinity, and plotting light separately for control and $\mathrm{N}$-enriched mesocosms to show the variability imposed by crab activity in replicate $\mathrm{N}-3$
Growth of macroalgae and Zostera marina was highly variable among replicates of both controls and $\mathrm{N}$-enriched mesocosms. The green macroalga Chaetomorpha linum (O. F. Müller) Kütz. (Chlorophyceae) bloomed in control replicate $1(\mathrm{C}-1)$, so that the highest macroalgal biomass from unenriched mesocosms occurred in that replicate except during late April, when the brown macroalga Ectocarpus siliculosus Sauvageau (Phaeophyceae) increased in C-3 (Fig. 4). Macroalgal abundance was comparable among controls and enriched mesocosms $\left(<80 \mathrm{~g} \mathrm{~m}^{-2}\right.$, with mean abundance $\leq 35 \mathrm{~g} \mathrm{~m}^{-2}$ ) except in $\mathrm{N}-3$, where the green macroalgae Enteromorpha spp. and Cladophora montagneana Kütz. were dominant with maxima in dry weight during late April $\left(235 \mathrm{~g} \mathrm{~m}^{-2}\right)$ and June $(485 \mathrm{~g}$ $\mathrm{m}^{-2}$ ) respectively (Fig. 4). In N-3, Enteromorpha spp. produced most of the macroalgal biomass during April, whereas $C$. montagneana and $E$. siliculosus were codominant in June. Macroinvertebrate densities were comparable in controls and $\mathrm{N}$-enriched mesocosms throughout most of the experiment, except that amphipods were ca 5 -fold more abundant in controls during the first $2 \mathrm{wk}(\mathrm{p}<0.05$; Fig. 5). There was no significant correlation between macroinvertebrate densities and macroalgal abundances, with or without nitrate enrichment.

Zostera marina leaf growth was similar among control and enriched mesocosms throughout the experiment, except for significantly higher growth by control plants at Week $12(p<0.05$; Fig. 6$)$. Attack of leaf tissue
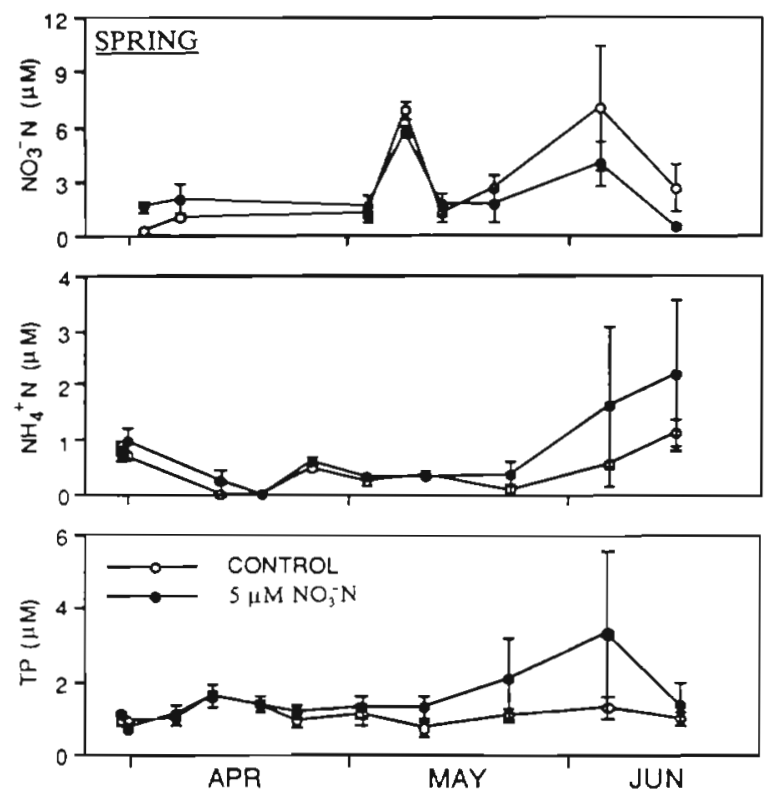

Fig. 3. Nutrient concentrations (means $\pm 1 \mathrm{SE}$ ) of $\mathrm{NO}_{3}{ }^{-} \mathrm{N}$, $\mathrm{NH}_{4}{ }^{+}-\mathrm{N}$ and TP during the spring experiment testing the response of Zostera marina to $5 \mu \mathrm{M} \mathrm{NO}_{3}{ }^{-}-\mathrm{N}$ enrichment 


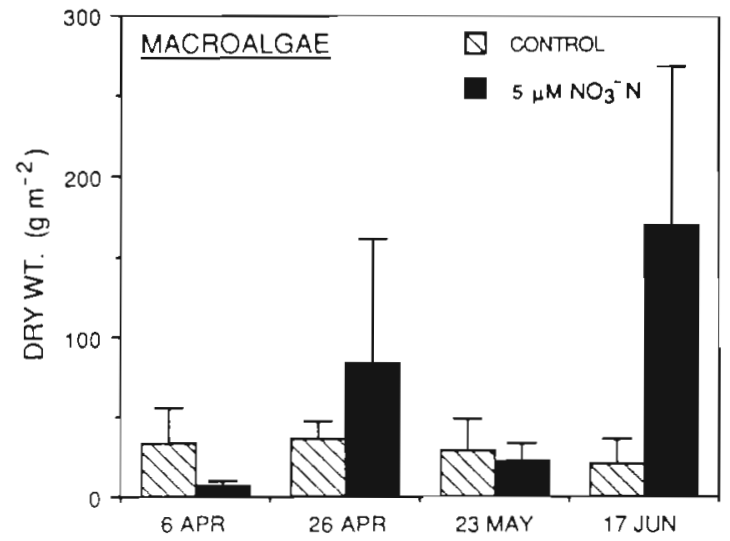

Fig. 4. Total abundance (means $+1 \mathrm{SE}$ ) of macroalgae during the spring experiment, as harvested dry weight per unit sediment surface area
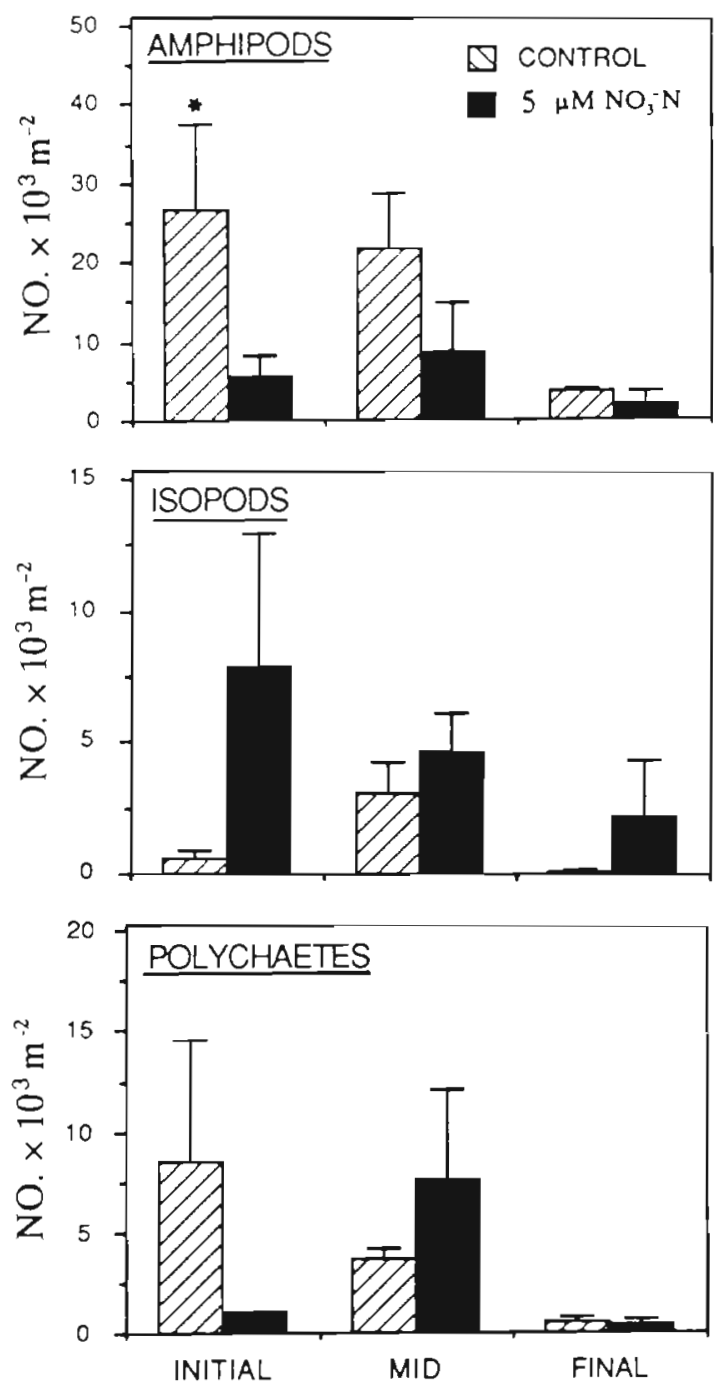

Fig. 5. Densities (means $+1 \mathrm{SE}$ ) of the 3 most abundant components of the macroinvertebrate community during the spring experiment, as individuals per unit sediment surface area. 'Signficantly higher abundance $(p<0.05)$
Table 1 Zostera marina. Content (\% dry weight, means $\pm 1 \mathrm{SE}$ ) of $\mathrm{C}, \mathrm{N}$ and $\mathrm{P}$ in aboveground and belowground eelgrass during the spring experiment. Data given for replicate control and enriched ( $\left.5 \mu \mathrm{M} \mathrm{NO}_{3}{ }^{-}-\mathrm{N}\right)$ mesocosms using pooled values of 12 to 15 shoots for each mesocosm. 'Significant differences from shoot content in controls $(p<0.05)$

\begin{tabular}{|c|c|c|c|}
\hline Date & Tissue & Control & $5 \mu \mathrm{M} \mathrm{NO}{ }^{-}-\mathrm{N}$ \\
\hline \multicolumn{4}{|l|}{ Carbon } \\
\hline 24 Apr & $\begin{array}{l}\text { Aboveground } \\
\text { Belowground }\end{array}$ & $\begin{array}{l}35.52 \pm 0.33 \\
32.15 \pm 0.52\end{array}$ & $\begin{array}{l}34.94 \pm 0.25 \\
31.67 \pm 0.49\end{array}$ \\
\hline 17 May & $\begin{array}{l}\text { Aboveground } \\
\text { Belowground }\end{array}$ & $\begin{array}{l}35.41 \pm 0.55 \\
31.08 \pm 0.87\end{array}$ & $\begin{array}{l}34.77 \pm 0.36 \\
30.10 \pm 0.98\end{array}$ \\
\hline 17 Jun & $\begin{array}{l}\text { Aboveground } \\
\text { Belowground }\end{array}$ & $\begin{array}{l}35.33 \pm 0.20 \\
31.28 \pm 0.74\end{array}$ & $\begin{array}{r}35.54 \pm 0.16 \\
\cdot 29.46 \pm 0.56\end{array}$ \\
\hline \multicolumn{4}{|c|}{ Nitrogen } \\
\hline $24 \mathrm{Apr}$ & $\begin{array}{l}\text { Aboveground } \\
\text { Belowground }\end{array}$ & $\begin{array}{l}1.44 \pm 0.04 \\
0.74 \pm 0.00\end{array}$ & $\begin{array}{r}1.62 \pm 0.14 \\
\cdot 0.81 \pm 0.02\end{array}$ \\
\hline 17 May & $\begin{array}{l}\text { Aboveground } \\
\text { Belowground }\end{array}$ & $\begin{array}{l}1.42 \pm 0.09 \\
0.75 \pm 0.03\end{array}$ & $\begin{array}{l}1.60 \pm 0.08 \\
0.76 \pm 0.05\end{array}$ \\
\hline 17 Jun & $\begin{array}{l}\text { Aboveground } \\
\text { Belowground }\end{array}$ & $\begin{array}{l}1.45 \pm 0.07 \\
0.78 \pm 0.05\end{array}$ & $\begin{array}{r}\cdot 1.78 \pm 0.04 \\
0.87 \pm 0.02\end{array}$ \\
\hline \multicolumn{4}{|c|}{ Phosphorus } \\
\hline $24 \mathrm{Apr}$ & $\begin{array}{l}\text { Aboveground } \\
\text { Belowground }\end{array}$ & $\begin{array}{l}0.21 \pm 0.01 \\
0.20 \pm 0.01\end{array}$ & $\begin{array}{l}0.21 \pm 0.01 \\
0.19 \pm 0.02\end{array}$ \\
\hline 17 May & $\begin{array}{l}\text { Aboveground } \\
\text { Belowground }\end{array}$ & $\begin{array}{l}0.18 \pm 0.01 \\
0.17 \pm 0.01\end{array}$ & $\begin{array}{l}0.19 \pm 0.01 \\
0.17 \pm 0.03\end{array}$ \\
\hline 17 Jun & $\begin{array}{l}\text { Aboveground } \\
\text { Belowground }\end{array}$ & $\begin{array}{l}0.18 \pm 0.01 \\
0.15 \pm 0.02\end{array}$ & $\begin{array}{l}0.19 \pm 0.03 \\
0.11 \pm 0.01\end{array}$ \\
\hline
\end{tabular}

by the pathogen Labyrinthula zosterae also was similar in enriched plants and controls throughout the experiment $(8 \pm 4 \%$ versus $5 \pm 3 \%$ invasion of control and enriched shoots, respectively; $n=12$ dates), suggesting that the low water-column nitrate enrichment did not increase eelgrass susceptibility to this opportunistic disease vector. By the end of the experiment, $\mathrm{N}$ enriched eelgrass had significantly higher aboveground tissue nitrogen content than controls ( $p<0.05$; Table 1), indicating that a portion of the water-column nitrate source had been taken up by the plants. Further, belowground tissue carbon content was significantly lower in enriched than in control shoots (Table 1). NRase activity was highly variable among the nitrate-enriched plants; mean NRase activity after 3 wk was not significantly different between control and enriched shoots, although there was a trend for higher NRase activity under nitrate enrichment (leaf NRase $18 \pm 7$ versus $57 \pm 52 \mu \mathrm{MNO}_{2}^{-} \mathrm{g}^{-1} \mathrm{~h}^{-1}$ in control and $\mathrm{N}$-enriched eelgrass respectively; belowground tissue NRase activity $17 \pm 4$ versus $28 \pm 8 \mu \mathrm{M} \mathrm{NO}_{2}^{-} \mathrm{g}^{-1}$ $\mathrm{h}^{-1}$ in control and $\mathrm{N}$-enriched shoots respectively). Total $\mathrm{C} / \mathrm{N}$ ratios in aboveground tissue were similar in control and $\mathrm{N}$-enriched plants, but belowground tissue 
Table 2. Zostera marina. Tissue $\mathrm{C} / \mathrm{N}$ and $\mathrm{N} / \mathrm{P}$ ratios (means \pm 1 SE) during the spring 1992 experiment for aboveground and belowground tissue in replicate control and enriched (5 $\mu \mathrm{M} \mathrm{NO}_{3}{ }^{-} \mathrm{N}$ ) mesocosms. "Significant differences from shoot content in controls $(p<0.05)$

\begin{tabular}{|llcc|}
\hline Date & \multicolumn{1}{c}{ Tissue } & Control & $5 \mu \mathrm{M} \mathrm{NO}_{3}{ }^{-}-\mathrm{N}$ \\
\hline C/N & & & \\
$24 \mathrm{Apr}$ & Aboveground & $24.6 \pm 1.1$ & $21.9 \pm 3.2$ \\
& Belowground & $43.7 \pm 0.7$ & $\cdot 39.1 \pm 1.6$ \\
$17 \mathrm{May}$ & Aboveground & $25.2 \pm 2.9$ & $21.8 \pm 1.8$ \\
& Belowground & $41.4 \pm 2.7$ & $40.0 \pm 2.2$ \\
$17 \mathrm{Jun}$ & Aboveground & $24.5 \pm 3.2$ & $20.0 \pm 0.6$ \\
& Belowground & $40.1 \pm 2.0$ & $\cdot 33.8 \pm 2.5$ \\
\multirow{2}{*}{ N/P } & & & \\
24 Apr & Aboveground & $6.9 \pm 0.3$ & $7.7 \pm 0.7$ \\
& Belowground & $3.6 \pm 0.3$ & $4.4 \pm 0.6$ \\
\multirow{2}{*}{ 17 Jay Jun } & Aboveground & $8.0 \pm 0.8$ & $8.5 \pm 0.5$ \\
& Belowground & $4.4 \pm 0.6$ & $4.8 \pm 2.7$ \\
& Aboveground & $8.3 \pm 1.1$ & $9.6 \pm 1.6$ \\
& Belowground & $5.2 \pm 0.7$ & $\cdot 7.9 \pm 0.6$ \\
\hline
\end{tabular}

$\mathrm{C} / \mathrm{N}$ ratios were significantly higher in controls after 4 and $12 \mathrm{wk}$ ( $\mathrm{p}<0.05$; qualitatively higher belowground tissue $\mathrm{C} / \mathrm{N}$ ratios in controls after $8 \mathrm{wk}$, also; Table 2). Throughout the experiment, there was a qualitative trend for higher $\mathrm{N} / \mathrm{P}$ ratios in aboveground tissue of $\mathrm{N}$-enriched plants relative to controls. Further, by Week 12 the N/P ratio of belowground tissue was significantly higher in $\mathrm{N}$-enriched plants than in controls $(\mathrm{p}<0.05$; Table 2).

The population-level index, shoot density, was variable in spring, with negligible eelgrass shoot production in 2 of 3 control replicates and a $24 \%$ decline in shoot numbers from $\mathrm{C}-3$ by the end of the experiment (Fig. 7). This decline apparently was unrelated to macroalgal abundance, which remained low in C-3 even during the Ectocarpus siliculosus increase (maximum at $58 \mathrm{~g}$ dry $w \mathrm{t} \mathrm{m}^{-2}$ in April, then 6 to $8 \mathrm{~g}$ dry $w \mathrm{t}$ $\mathrm{m}^{-2}$ during May-June; Fig. 4). Among nitrateenriched mesocosms, shoot numbers increased slightly in N-1 and N-2, but there was a $44 \%$ decline in shoots

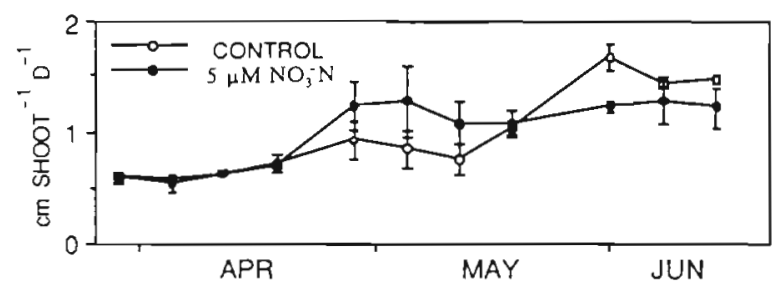

Fig. 6. Zostera marina. Leaf growth of eelgrass (elongation of all new leaves shoot ${ }^{-1} \mathrm{~d}^{-1}$ ) with/without $5 \mu_{\mathrm{M} \mathrm{NO}}{ }^{-}$-N water-column enrichment in the spring 1992 experiment (means $\pm 1 \mathrm{SE}$ ) of N-3. This decline coincided with both high macroalgal growth in N-3 (485 g dry wt $\mathrm{m}^{-2}$ ) and reduction in available light from both macroalgae and sediment dispersal associated with blue crab activity (Figs. 2, 4 $\& 7$ ). Significant influences on eelgrass growth by temperature, salinity, PAR, macroalgal abundance, or macroinvertebrate densities were not detected in statistical analyses. Hence, the data, although variable, indicated comparable growth by eelgrass under control and low nitrate-enriched regimes during this unusually cold spring.

\section{Fall experiment: community response to moderate nitrate enrichment}

Autumn was characterized by cool temperatures that were similar to or slightly lower $\left(1\right.$ to $\left.2^{\circ} \mathrm{C}\right)$ than longterm monthly averages (NOAA 1993). Mesocosm water temperatures gradually decreased from maxima at 27 to $29^{\circ} \mathrm{C}$ in September to a minimum of $9^{\circ} \mathrm{C}$ in mid-November (Fig. 8). This minimum was followed by a temporary warming period when temperatures increased to $18^{\circ} \mathrm{C}$ and then declined to ca $16^{\circ} \mathrm{C}$ by the end of the experiment. A series of overcast days and precipitation events from late September through midOctober coincided with reduced salinity (Fig. 8). Minimal salinity of $23 \%$ occurred during early October; by the third week in October, salinity had increased to a

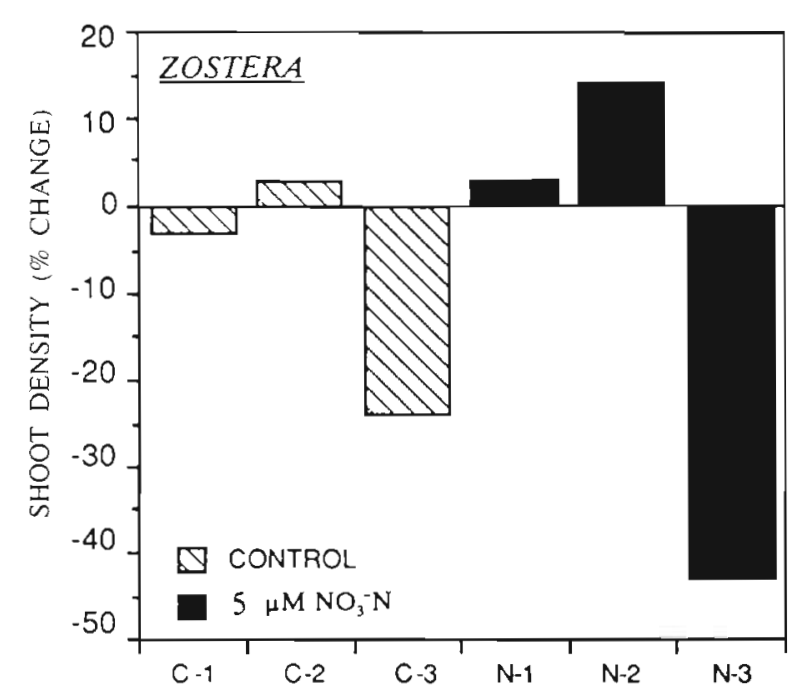

Fig. 7. Zostera marina. Change in shoot densities of eelgrass populations in control and $5 \mu \mathrm{M} \mathrm{NO}_{3}{ }^{-}-\mathrm{N}$-enriched mesocosms from the beginning to the end of the spring experiment (as \% change in shoot numbers). Individual replicates are plotted, given the variation in response within each treatment. Note: the lowest eelgrass shoot production in C-3 also coincided with low macroalgal production, whereas lowest shoot production in $\mathrm{N}-3$ coincided with highest macroalgal growth 

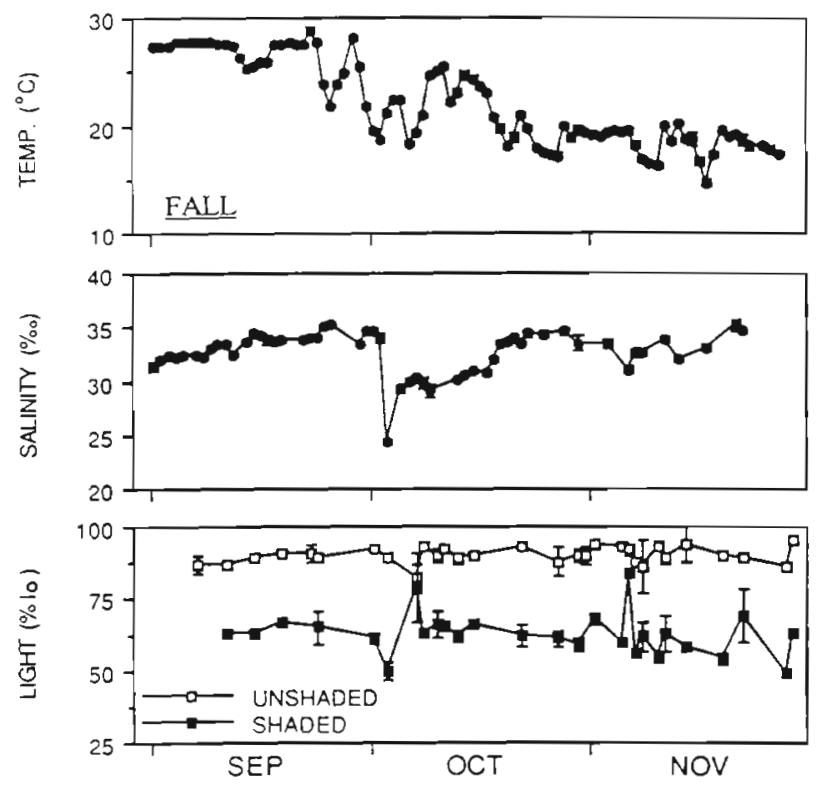

Fig. 8. Temperature, salinity, and light (means $\pm 1 \mathrm{SE}$ ) at the base of the canopy during the late summer-fall 1992 experiment for control and $10 \mu \mathrm{M} \mathrm{NO}{ }_{3}^{-}-\mathrm{N}$-enriched mesocosms, considered collectively in all plots). PAR includes both shaded and unshaded data to show the decrease that occurred when plants were shaded for $3 \mathrm{~h} \mathrm{~d}^{-1}$ to simulate light reduction from high tide

similar range ( 30 to $35 \%$ ) as before the rainstorms. As in spring, light was non-limiting (Dennison \& Alberte 1982); more than $75 \%$ of the PAR just below the water surface was available within the Zostera marina canopy, decreasing to more than ca $50 \%$ availability when plants were shaded for $3 \mathrm{~h}$ daily to simulate light reduction from high tide (Fig. 8). Nitrate concentrations in control mesocosms were comparable to those in the enriched treatment during most of the first $7 \mathrm{wk}$ (Fig. 9). In the latter part of the experiment, however, nitrate usually was higher in the $\mathrm{N}$-enriched regime, indicating water-column accumulation over time (range up to ca $21 \mu \mathrm{M} \mathrm{NO}_{3}^{-}-\mathrm{N}_{\text {i }}$ significantly higher in $\mathrm{N}$-treated than in control mesocosms after $24 \mathrm{~h}$ on 3 dates; $\mathrm{p}<0.05$; Fig, 9). As during spring, $\mathrm{NH}_{4}{ }^{+}-\mathrm{N}$ and TP generally were low and comparable among control and enriched mesocosms (Fig. 9).

Macroalgal abundance was low (ca $50 \mathrm{~g}$ dry wt $\mathrm{m}^{-2}$ ) in controls and in 1 nitrate-enriched replicate $(\mathrm{N}-1$; Fig. 10). Enriched mesocosm N-2 developed dense growth of the red macroalga Polysiphonia sp., with maximal accumulation by mid-October (ca $330 \mathrm{~g}$ dry wt $\mathrm{m}^{-2}$ ). This alga covered the sediment and walls, but mostly occurred as an epiphyte on all 3 macrophyte species with noticeably thicker coverage on stems and leaves of Ruppia maritima. Polysiphonia sp. declined to approximately $75 \mathrm{~g}$ dry wt $\mathrm{m}^{-2}$ in the second enriched replicate by mid-November. As for macro-
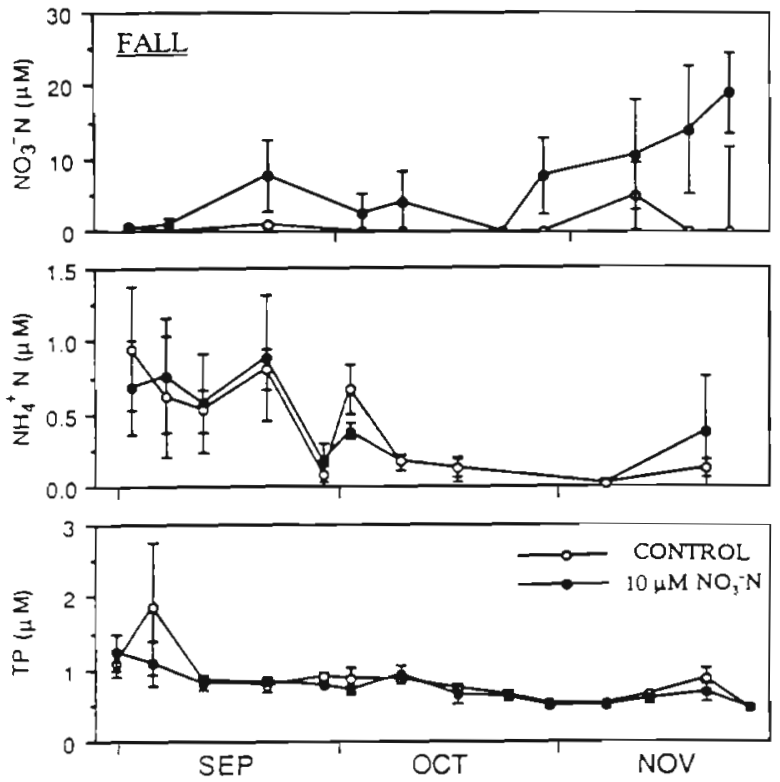

Fig. 9. Concentrations (means $\pm 1 \mathrm{SE}$ ) of $\mathrm{NO}_{3}{ }^{-}-\mathrm{N}, \mathrm{NH}_{4}{ }^{+}-\mathrm{N}$ and TP during the late summer-fall experiment testing the response of 3 macrophyte species to $10 \mu \mathrm{M} \mathrm{NO}{ }_{3}^{-}-\mathrm{N}$ enrichment

algae, macroinvertebrate densities, again, were highly variable (Fig. 11). N-2 initially supported abundant isopods $\left(134.1 \times 10^{3}\right.$ ind. $\mathrm{m}^{-2}$ sediment area, versus 8.7 $\times 10^{3}$ ind. $\mathrm{m}^{-2}$ in the other mesocosms). By December amphipod densities were highest in replicate $\mathrm{N}$-1 $\left(402.4 \times 10^{3}\right.$ ind. $\left.\mathrm{m}^{-2}\right)$, and mean amphipod densities

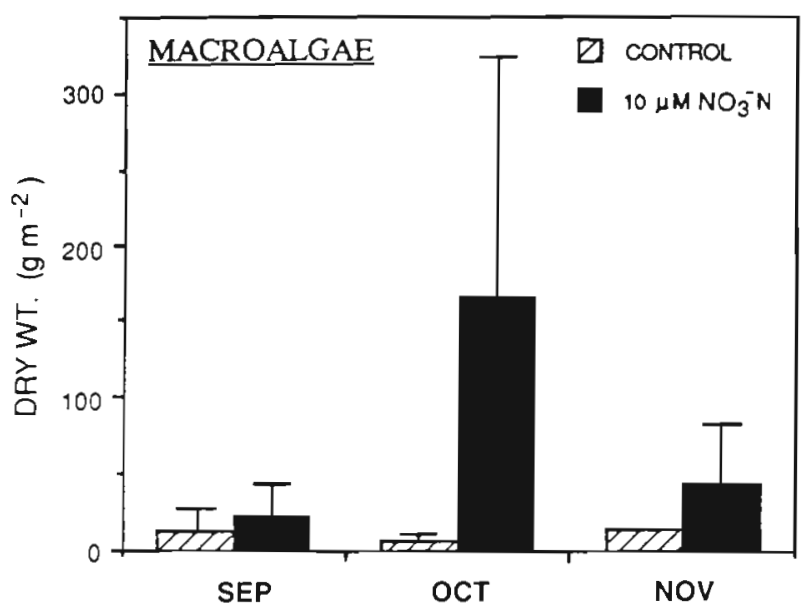

Fig. 10. Response of macroalgae to $10 \mu \mathrm{M} \mathrm{NO}_{3}{ }^{-}-\mathrm{N}^{-}$enrichment in the late summer-fall experiment, as harvested dry weight per unit sediment surface area (means $+1 \mathrm{SE}$ ). Note that although there was a trend for higher macroalgal biomass under nitrate enrichment, the variability in macroalgal response resulted in production that was not significantly different in control versus enriched mesocosms 
were significantly higher in $\mathrm{N}$-enriched mesocosms than in controls $(p<0.05 ;$ Fig. 11). Polychaetes were significantly more abundant among nitrate-enriched replicate mesocosms than in controls ( $p<0.05$ ), perhaps suggesting a positive (indirect) effect of watercolumn nitrate in increasing organic detritus and other food resources.

\section{Zostera marina, Halodule wrightii and Ruppia maritima under moderate nitrate enrichment}

Eelgrass growth was less variable in fall than during spring. As in spring, similar although 2-fold higher invasion by the pathogen Labyrinthula zosterae was observed in the leaf tissue of control and $\mathrm{N}$-enriched
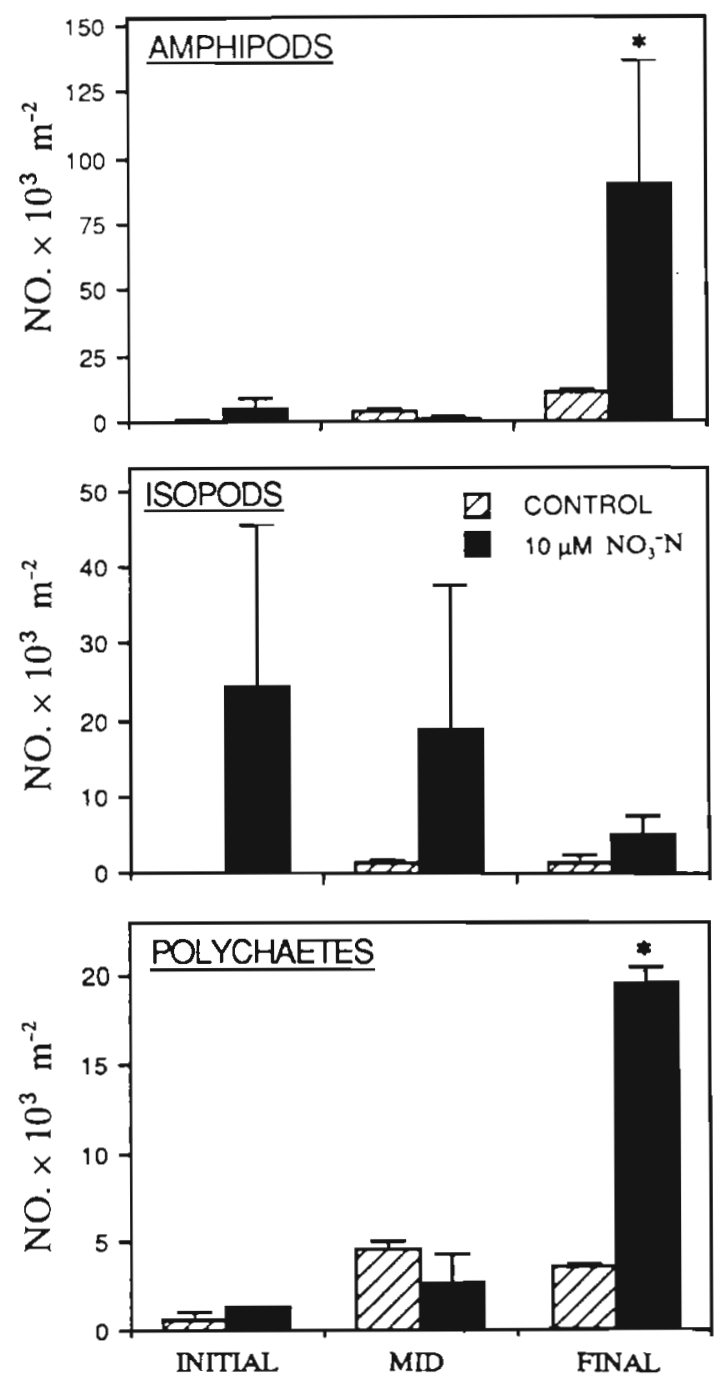

Fig. 11. Densities of the 3 most abundant components of the macroinvertebrate community during the late summer-fall experiment, as individuals per unit sediment surface area (means $+1 \mathrm{SE})$. Significantly higher abundance $(p<0.05)$ plants $(18 \pm 4 \%$ versus $25 \pm 8 \%$ infection, respectively; $\mathrm{n}=3$ dates in early, mid and late fall). Higher NRase activity $\left(410 \pm 120 \mathrm{nM} \mathrm{NO}_{2}^{-} \mathrm{g}^{-1} \mathrm{~h}^{-1}\right.$ and $820 \pm 50 \mathrm{nM}$ $\mathrm{NO}_{2}^{-} \mathrm{g}^{-1} \mathrm{~h}^{-1}$ in control and enriched plants, respectively, after 3 wk), higher $\mathrm{N}$ tissue content, higher $\mathrm{C} / \mathrm{N}$ ratios, and lower N/P ratios in above- and belowground tissue of $\mathrm{N}$-enriched plants relative to controls indicated that the enriched plants had taken up a portion of the nitrate ( $p<0.05$; Figs. 12, $13 \& 14)$. The aboveground meristem regions of $\mathrm{N}$-enriched plants were structurally intact and similar in appearance to the meristems of control plants after $3 \mathrm{wk}$ and $10 \mathrm{wk}$. Total protein content was similar among control and $\mathrm{N}$-enriched shoots at $3 \mathrm{wk}$, whereas GS activity was lower in $N$-enriched plants (GS at $42 \pm 1$ versus $31 \pm$ $6 \mathrm{mmol} \gamma$-glutamyl hydroxamate $\mathrm{g}^{-1}$ tissue in controls and $\mathrm{N}$-enriched plants, respectively, after $3 \mathrm{wk}_{\text {; }} \mathrm{p}<$ 0.06 ; Figs. $12 \& 15$ ).

By the end of the experiment (11 to $14 \mathrm{wk}$ ) in enriched eelgrass, however, the carbon content of belowground tissue and the total dissolved carbohydrates of both above- and belowground tissue were significantly lower than in controls $[p<0.05$; Figs. 13
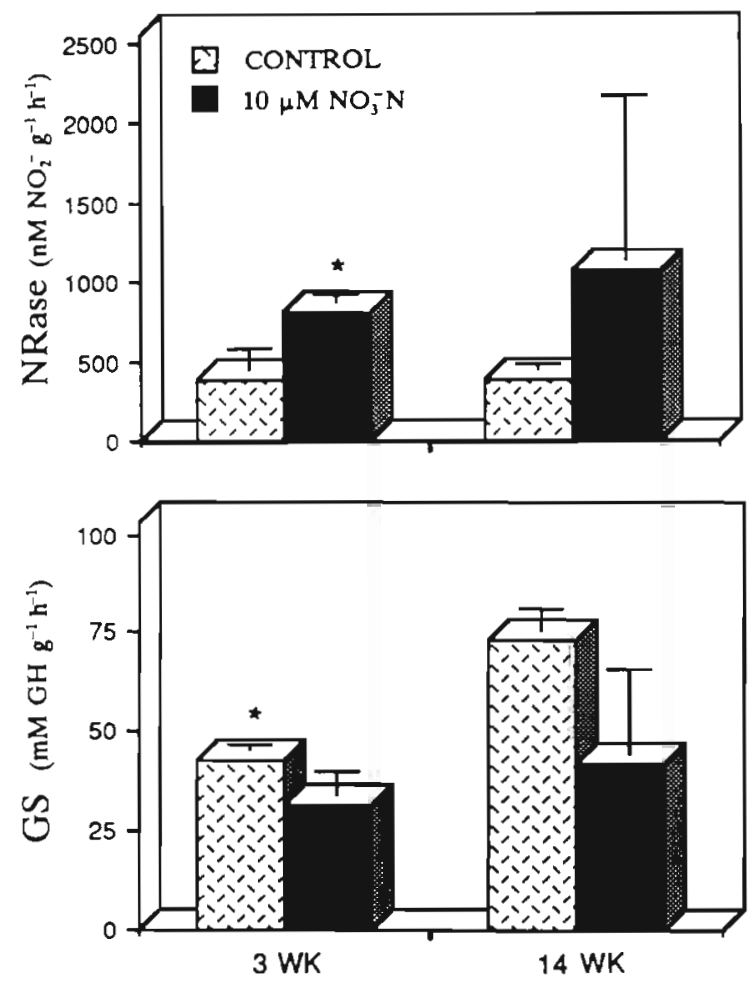

Fig. 12. Zostera marina. Nitrate reductase (NRase) and glutamine synthetase (GS) activities (means + $1 \mathrm{SE}$ ) in aboveground tissue of control and $\mathrm{N}$-enriched (10 $\mu \mathrm{M} \mathrm{NO}_{3}{ }^{-}$) recently transplanted eelgrass after 3 and $14 \mathrm{wk}$ in the late summer-fall experiment. - Significantly higher activity $(p<0.05)$ 


\section{$\square$ CONABOVE N-ENRICH ABOVE
$\square$ CONBELOW}
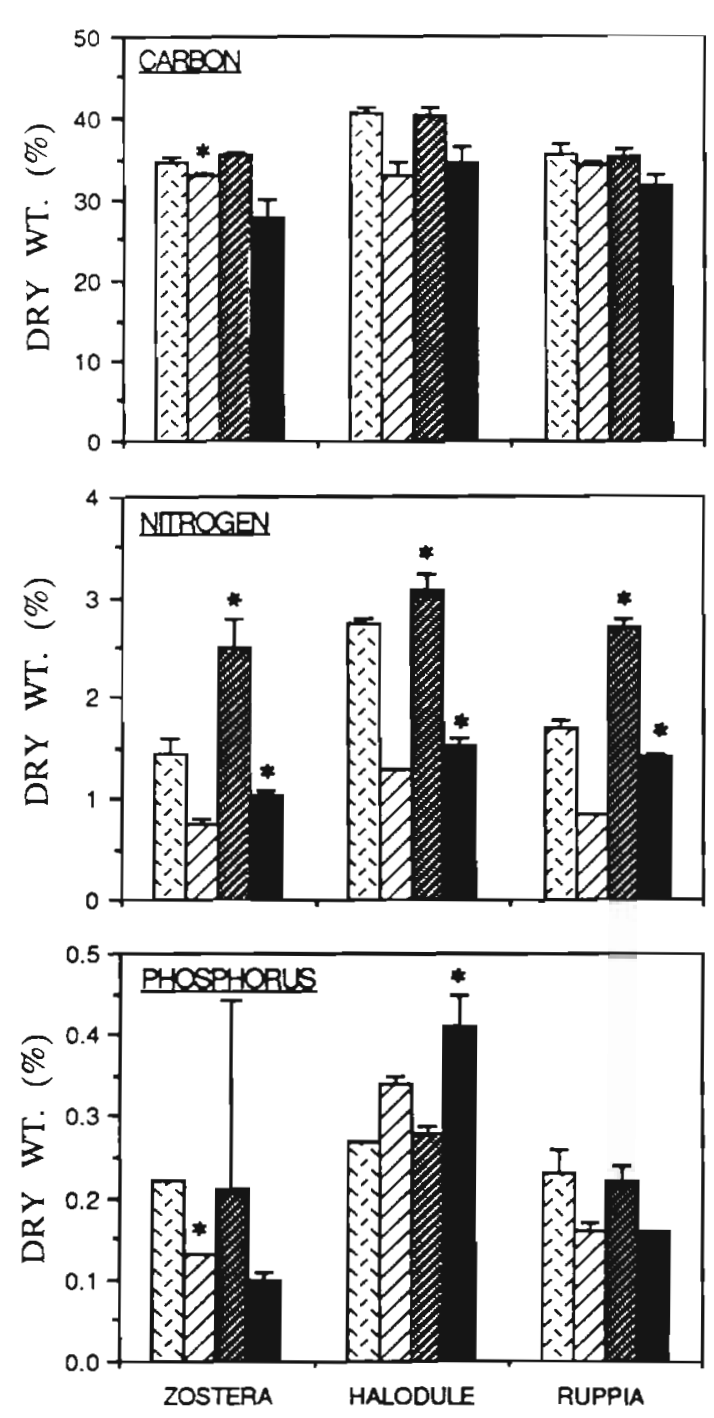

Fig. 13. Zostera marina, Halodule wrightii, and Ruppia maritima. Tissue content ( $\%$ dry wt, means $+1 \mathrm{SE}$ ) of $\mathrm{C}, \mathrm{N}$ and $\mathrm{P}$ in above-and belowground tissue of recent transplants after $11 \mathrm{wk}$ in the late summer-fall experiment for replicate control and enriched $\left(10 \mu \mathrm{M} \mathrm{NO}_{3}^{-} \mathrm{N}\right)$ mesocosms. For each mesocosm, pooled values of 12 to $15 \mathrm{Z}$. marina plants and ca 50 shoots of the smaller $H$. wrightii and $R$. maritima plants were used. "Significantly higher tissue content of control or $\mathrm{N}$ enriched plants, considering each species separately $(p<0.05)$

\& 15). Plants in the $N-1$ replicate apparently were most adversely affected by water-column nitrate; after $14 \mathrm{wk}$ NRase activity of $\mathrm{N}-1$ plants was much lower than that of plants from other $\mathrm{N}$-enriched or control mesocosms (in $2 \mathrm{~h}$ assays, $250 \mathrm{nM} \mathrm{NO}_{2}^{-} \mathrm{g}^{-1}$ tissue fresh wt $\mathrm{h}^{-1}$ in the $\mathrm{N}-1$ replicate, versus $>2000 \mathrm{nM} \mathrm{NO}_{2}^{-} \mathrm{g}^{-1}$ fresh wt $h^{-1}$ in the other $\mathrm{N}$-enriched replicate and 430
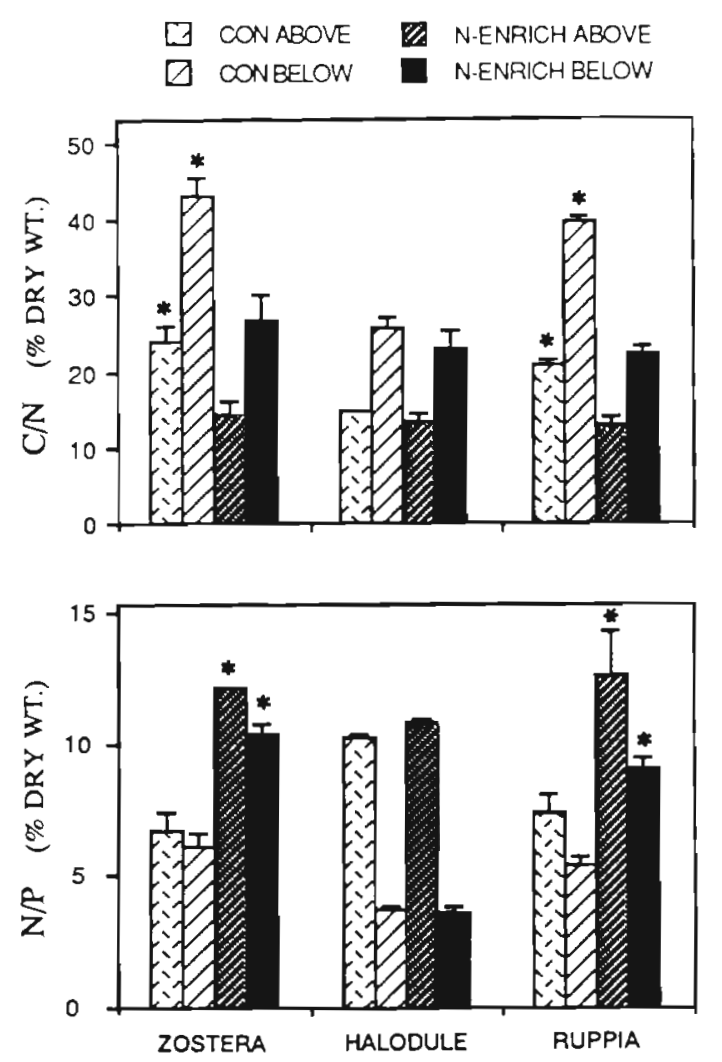

Fig. 14. Zostera marina, Halodule wrightii, and Ruppia maritima. Tissue $\mathrm{C} / \mathrm{N}$ and $\mathrm{N} / \mathrm{P}$ ratios (\% dry $w \mathrm{t}$, means $+\mathrm{SE}$ ) of recent transplants after $11 \mathrm{wk}$ in the late summer-fall experiment. Data are given as in Fig. 13

$\pm 10 \mathrm{nM} \mathrm{NO}_{2}^{-} \mathrm{g}^{-1}$ fresh wt ${ }^{-1}$ in controls; Fig. 12). The $\mathrm{P}$ content of aboveground tissue in the $\mathrm{N}-1$ eelgrass was also low and suggestive of $\mathrm{P}$ limitation (Duarte 1990), in comparison to plants from the other enriched and control mesocosms $1<0.08 \%$ in $\mathrm{N}-1$ shoots versus $>0.20 \%$ in plants from the other $\mathrm{N}$-enriched replicate and controls; Fig. 13).

These data indicate that internal nutrient imbalances of the $\mathrm{N}-1$ eelgrass plants, in particular, were severe. Moreover, whereas nitrate-enriched eelgrass generally became weakened and easily fragmented in the shoot meristem region, the 'crumbling meristem' condition (Burkholder et al. 1992) was visibly most pronounced from eelgrass in the $\mathrm{N}-1$ replicate and coincided with higher water-column phosphorus than measured in previous weeks $165 \mu \mathrm{g} \mathrm{TP} \mathrm{l}^{-1}$ in N-1 at $14 \mathrm{wk}$ versus $20 \mu \mathrm{g} \mathrm{TP}^{-1}$ at $13 \mathrm{wk}$, based on duplicate subsamples]. Further, in the $N-1$ eelgrass with obvious meristem deterioration, fungal hyphae were found after $14 \mathrm{wk}$ in meristem cross-sections from 3 of 6 examined shoots, suggesting secondary invasion by an opportunistic pathogen. Similar increases in watercolumn TP, or of fungi in eelgrass meristems, were not 


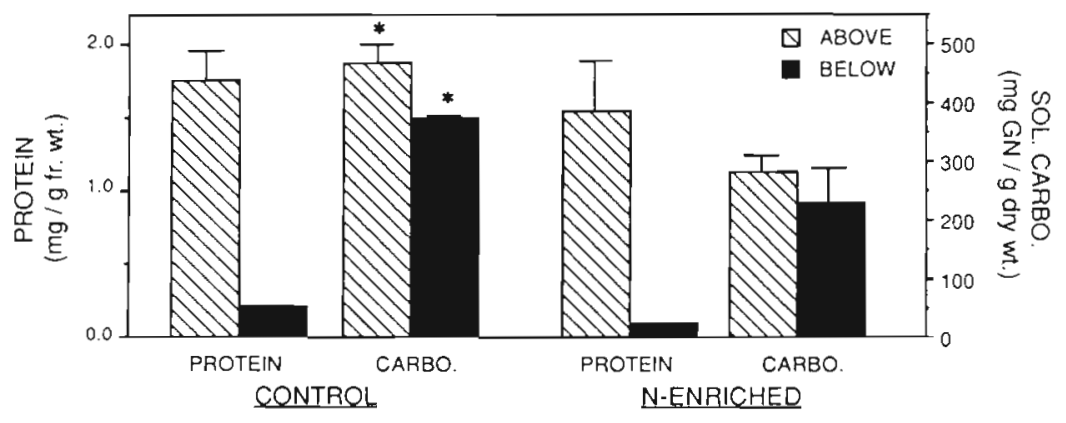

Fig. 15. Zostera marina. Total protein and acid-soluble (dissolved) carbohydrate content of recently transplanted eelgrass after $14 \mathrm{wk}$ in the late summer-fall experiment (means $+1 \mathrm{SE})$. "Significantly higher tissue content $(p<0.05)$. Note that for acid-soluble carbohydrates, a standard curve was produced using

D-glycogen and data were reported as $m g$ glycogen $\mathrm{g}^{-1}$ dried plant powder

cantly higher by control LTMA plants with no prehistory of nitrate enrichment than by the previously enriched LTMA shoots (spring) under nitrate loading in late summer-fall; the previous nitrate exposure apparently had weakened those plants so that their growth was significantly less than that of LTMA controls ( $p<0.05)$. Eelgrass without nitrate enrichment prehistory also showed a trend for decreased lateral growth relative to controls without elevated nitrate (Fig. 16).

In contrast to the negative effect of moderate water-column nitrate enrichment on Zostera marina (espe-

observed in other $\mathrm{N}$-enriched or control mesocosms; fungal hyphae were noted in 1 of 6 shoots examined from N-2, but were not found in the control shoots.

Eelgrass without nitrate enrichment prehistory showed a trend for decreased lateral growth (net change in shoot density) under moderate nitrate enrichment in fall, although shoot production of control and enriched plants was not significantly different (Fig. 16). The LTMA control Zostera marina produced significantly more shoots than did recent field transplant controls $(p<0.05)$. Lateral growth was signifi-

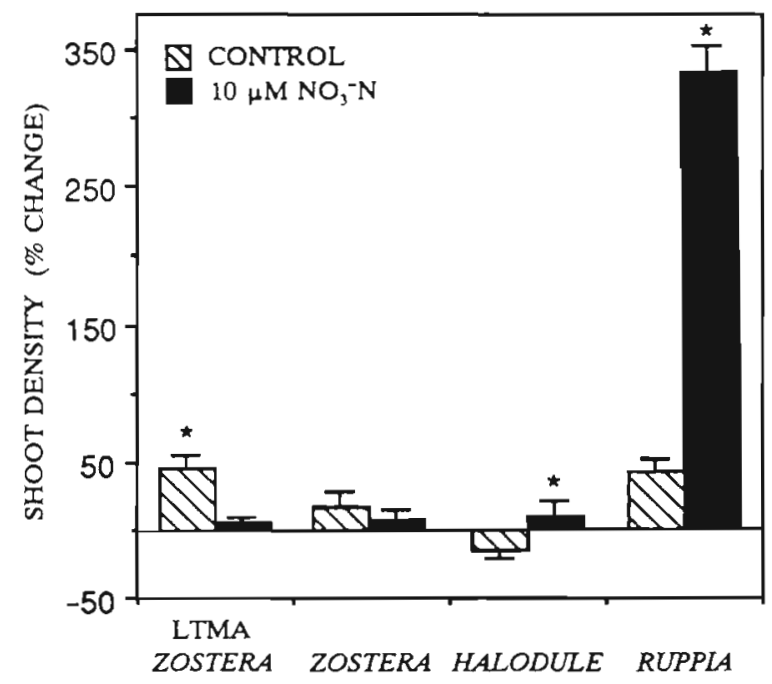

Fig. 16. Zostera marina, Halodule wrightii, and Ruppia maritima. Shoot production (lateral growth, means + SE) over the late summer-fall experiment, including long-term mesocosm-acclimated (LTMA) Z. marina with prehistory of watercolumn nitrate enrichment (in spring), and recent transplants without enrichment prehistory (initial and final dates compared as percent change in shoot numbers). 'Significantly higher shoot production of control or $\mathrm{N}$-enriched plants, considering each of the 4 plant types separately $(p<0.05)$ cially for the plants with 'pre-history' of nitrate enrichment during spring), at the population level Halodule wrightii was mildly stimulated by nitrate (Fig. 16). This species showed a small decline in shoot production by unenriched controls, and an increase in numbers of enriched shoots (significantly higher numbers of N-enriched shoots; $p<0.05$ ). Z. marina, $H$. wrightii and control Ruppia maritima increased in shoot density by $<50 \%$ during the experiment. $R$. maritima, however, was highly stimulated by pulsed moderate nitrate loading and increased shoot production by more than $300 \%$ (significantly greater lateral growth than shown by controls, enriched $Z$. marina, or enriched $H$. wrightii; $\mathrm{p}<0.05$ ).

Comparison of tissue $\mathrm{C}, \mathrm{N}$, and $\mathrm{P}$ content in these 3 macrophyte species suggested differences in internal nutrient supply allocations. Like the nitrate-enriched Zostera marina, enriched Halodule wrightii and Ruppia maritima were significantly higher in $\mathrm{N}$ content. This elevated tissue $\mathrm{N}$ was reflected as higher $\mathrm{C} / \mathrm{N}$ and $\mathrm{N} / \mathrm{P}$ ratios for enriched $Z$. marina and $R$. maritima relative to controls, indicating elevated nitrate uptake and tissue $\mathrm{N}$ accumulation ( $\mathrm{p}<0.05$; Figs. $13 \& 14$ ). In contrast, enriched $H$. wrightii maintained similar tissue $\mathrm{C} / \mathrm{N}$ and N/P ratios as controls, and the belowground tissue $\mathrm{P}$ content of this species was significantly higher in the $N$-enriched regime ( $p<0.05$; Figs. $13 \& 14$ ). Control $H$. wrightii appeared to have innately higher nutrient content than the other 2 species; the control plants were significantly higher in aboveground $C$, and in both above- and belowground $N$ and $P$, than control $Z$. marina or $R$. maritima ( $\mathrm{p}<0.05$; Fig. 13). Further, belowground tissue $C$ content was significantly depressed in $\mathrm{N}$-enriched $Z$. marina relative to that of unenriched controls ( $\mathrm{p}<0.05$, with a similar although non-significant trend in $R$. maritima), whereas $H$. wrightii maintained comparable belowground $\mathrm{C}$ with and without water-column nitrate enrichment. 


\section{DISCUSSION}

The simulation represented by this experiment namely, estuarine eutrophication as nitrate enrichment, rather than as ammonium enrichment or as a balance of $\mathrm{N}_{i}$ and $\mathrm{P}_{i}$ enrichment - is analogous to present conditions in many estuaries where seasonal $P$ limitation is induced by high $\mathrm{N}_{1}$ loading. Although septic effluent leachate, sewage and agricultural drainage all can be enriched in ammonium (Valiela et al. 1992), a high percentage of the ammonium generally adsorbs to particulate matter and settles out (Simon 1989), or is converted to nitrate as it is transported through oxygenated estuarine waters (Paasche 1988, Maier \& Pregnall 1990; but see Lapointe \& Clark 1992). Hence, estuaries draining agricultural/urban basins can be dominated by $\mathrm{NO}_{3}{ }^{-}$rather than $\mathrm{NH}_{4}{ }^{+}$, particularly during the critical spring growing season for Zostera marina (Rudek et al. 1991, Valiela et al. 1992). Nitrate is especially high relative to phosphorus in septic effluent that leaches to receiving coastal lagoons and upper embayments (Valiela \& Costa 1988, Maier \& Pregnall 1990, Valiela et al. 1990). Many estuaries additionally have received high nitrate loading from other anthropogenic sources such as acid deposition and agricultural runoff to the extent that, in an increasing trend, such systems have seasonally shifted to primary limitation of plant growth by $\mathrm{P}$ rather than $\mathrm{N}$, or to co-limitation by both $\mathrm{N}$ and $\mathrm{P}$ (Paerl et al. 1990, Rudek et al. 1991, Magnien et al. 1992, Jaworski et al. 1992).

During this unusually cold spring, low water-column nitrate enrichment ( $5 \mu \mathrm{M} \mathrm{NO}_{3}^{-}-\mathrm{N} \mathrm{d}^{-1}, 12 \mathrm{wk}$ ) did not discernibly affect shoot densities of eelgrass, although by the end of the experiment internal balances of nutrient supplies in $\mathrm{N}$-enriched plants had shifted relative to the nutrient content of unenriched controls. In previous research we demonstrated that during an unusually warm spring (water temperatures averaging $4^{\circ} \mathrm{C}$ above the $19 \mathrm{yr}$ weekly mean, or ca $7^{\circ} \mathrm{C}$ warmer than in spring 1992; taken from NOAA 1993) under otherwise similar experimental conditions, Zostera marina shoot densities decreased significantly after $8 \mathrm{wk}$ with only $3.5 \mu \mathrm{Mi} \mathrm{NO}{ }_{3}^{-}-\mathrm{N}$ in pulsed daily additions (Burkholder et al. 1992). Similarly, during an unusually warm autumn (water temperatures $3^{\circ} \mathrm{C}$ above the long-term weekly averages for 6 of 12 wk; NOAA 1993), nitrate loading at $7 \mu \mathrm{M} \mathrm{NO}_{3}{ }^{-}-\mathrm{N} \mathrm{d}^{-1}$ significantly reduced lateral growth of recently transplanted $Z$. marina relative to unenriched controls (Burkholder et al. 1992). Under cooler temperatures in fall 1992, however, recently transplanted eelgrass did not significantly decline over a comparable experimental duration at $10 \mu \mathrm{M} \mathrm{NO}_{3}-\mathrm{N} \mathrm{d}^{-1}$. Collectively, these findings point to potential synergism between warm temperatures and water-column nitrate enrichment in promot- ing eelgrass decline (e.g. Salisbury \& Ross 1978, North \& Zimmerman 1984).

The abiotic factors, warm temperature, elevated water-column nitrate, and reduced light, acting alone or in concert, previously have been shown to adversely affect macrophytes. Declines in plant growth from nitrate enrichment and imposed internal nutrient imbalances, as well as depressed carbohydrate synthesis, have been documented for terrestrial plants (Van Quy et al. 1991, Aber 1992), as well as for Zostera marina (Burkholder et al. 1992). In Z. marina warm temperatures have been found to 'drain' carbon reserves, resulting from associated high-respiration demands (Burke \& Dennison 1993) and from repressed activity of carbon translocation enzymes (Zimmerman et al. 1989). Moreover, experiments by Burke \& Dennison (1993) present compelling evidence that reduced light during the spring growing season can cause subsequent eelgrass declines through decreased production of the carbon reserves needed for plant survival during the warm summer period. These interacting factors - water-column nitrate enrichment, warm temperatures, and reduced light availability - characterize many estuaries during mid-spring through early summer, and they should be examined for potential synergism in promoting seasonal eelgrass habitat loss.

The enriched plants in N-3 from our cold-temperature spring 1992 experiment likely were influenced by the decrease in light availability that extended for a 3 wk period (Burke \& Dennison 1993), as well as by the elevated water-column nitrate. Small error bars in the tissue data for $\mathrm{N}$-enriched plants indicate that the 3 replicates remained similar in total $\mathrm{C}, \mathrm{N}$, and $\mathrm{P}$ content following increased light availability in the N-3 mesocosm; for example, belowground carbon content, reflecting carbon storage, was comparably depressed among the plants from all 3 enriched mesocosms relative to controls. Nonetheless, the N-3 plants were discarded after the spring nitrate exposure to avoid the potential confounding factor of the 3 wk difference in former light regime when interpreting spring $\mathrm{N}$ enriched plant response to subsequent nitrate enrichment. In the fall experiment, eelgrass with this prehistory of water-column nitrate loading was adversely affected by moderate nitrate additions, relative to the unenriched controls.

In contrast, $\mathrm{N}$-enriched eelgrass without prior exposure to elevated nitrate maintained a qualitative but non-significant decrease in shoot density in comparison to controls. Differences between plant duration in the mesocosms prevented statistical comparison of the LTMA populations from the spring-fall manipulation with the more recently transplanted eelgrass. However, the higher shoot growth shown by LTMA control plants relative to more recent field-transplanted con- 
trols suggests that the mesocosm environment did not negatively affect eelgrass, and that prehistory of water-column nitrate enrichment may weaken Zostera marina for survival under subsequent nitrate loading. Pre-exposed plants would be at a disadvantage if, for example, the high carbon demand resulting from sustained nitrate uptake and conversion to amino acids by leaf tissue (Turpin et al. 1988, Turpin 1991) interfered with carbohydrate synthesis or storage, or with production of anti-microbial phenolics (Bazzaz et al. 1987). Although we observed no apparent overall increase in the common pathogen Labyrinthula zosterae on $\mathrm{N}$-enriched eelgrass relative to controls, this effect has been reported by other researchers (Buchsbaum et al. 1990).

The data from this study indicate that water-column nitrate enrichment can change internal nutrient supply balances and impair carbohydrate metabolism in Zostera marina. Enriched and control plants were comparable in total protein content, but other N-containing constituents were not measured; for example, excess nitrogen in the enriched eelgrass could have accumulated as free amino acids or other $\mathrm{N}$-containing, nonproteinaceous components. The low NRase, high tissue $N$, extremely low aboveground tissue $P$, and meristem condition of the N-1 plants collectively were considered to provide evidence that these plants were moribund after $14 \mathrm{wk}$ of water-column nitrate loading. Eelgrass from the N-2 replicate likely would have followed a similar course, had the late summer-fall experiment been extended. In previous experiments (Burkholder et al. 1992) and in N-1, the 'crumbling meristem' condition of nitrate-enriched shoots preceded plant death by 1 to $2 \mathrm{wk}$, and coincided with significantly higher water-column total phosphorus concentrations than in previous weeks. One possible explanation is that the enriched eelgrass shoots lost membrane structural integrity prior to death, resulting in substantial P leakage (reported, for example, in stressed terrestrial plants prior to death; Levitt 1980). Microbial pathogens could become opportunistic secondary invaders once plants were weakened from stress imposed by internal nutrient supply imbalances, as was noted particularly for enriched plants from the N-1 mesocosm.

Mean water-column nitrate concentrations measured during our experiments were within the range of values commonly reported for estuaries under accelerated eutrophication (Rudek et al. 1991, Monbet 1992, Neckles 1993). When considered against our known imposed loadings and concentration maxima, however, these data suggest a critical need for improved techniques to evaluate actual nutrient exposure for seagrasses, especially during sensitive growth periods. Unless sampling was both well-timed and frequent, major loading events could easily be missed because of removal (e.g. plant uptake and export processes; Maier \& Pregnall 1990, Rudek et al. 1991). As a supplement to 'instantaneous' assessment of nutrient regime on the basis of concentrations, indices based on eelgrass tissue $\mathrm{C}, \mathrm{N}$ and $\mathrm{P}$ content, or on ratios of these nutrients, should be developed as parameters that integrate more long-term (days to weeks) fluctuations in nutrient supplies for seagrasses in localized areas where nutrient enrichment is suspected (analogous to use of Thalassia testudinum Banks ex König tissue C:N:P content by Fourqurean et al. 1993 to infer ecosystem- or regional-scale nutrient availability).

In future work, determination of the fate of incorporated excess nitrate, including associated phosphorus demands and carbon 'sinks', will provide insights about the physiological mechanisms underlying inhibition of Zostera marina by elevated water-column nitrate. The mild/strong stimulatory effect of nitrate on Halodule wrightii and Ruppia maritima under moderate enrichment suggests that unlike Zostera marina, these species have developed more advantageous physiological mechanisms for controlling nitrate uptake and assimilation from the water. $H$. wrightii and $R$. maritima are considered to co-exist with eelgrass on the North Carolina coast; their innate seasonality is believed to preclude sustained competitive interactions with the more cold-optimal $Z$. marina (Thayer et al. 1984). In natural habitats under watercolumn nutrient enrichment from septic effluent leachate and other sources, however, R. maritima and $H$. wrightii have been observed to survive where eelgrass disappears from formerly mixed beds, without reappearance of $Z$. marina in colder seasons (Batiuk et al. 1992, Dennison et al. 1993, Burkholder unpubl. data; but see Harlin \& Thorne-Miller 1981). H. wrightii and $R$. maritima have also been reported in abundance from nutrient-enriched or hypereutrophic tropical areas, rather than the more widespread tropical dominant seagrass, Thalassia testudinum (Powell et al. 1991, Lapointe \& Tomasko 1993).

Our research indicates that in enriched locations where eelgrass has declined, Halodule wrightii or Ruppia maritima might be successfully transplanted to reestablish vegetated coastal habitat - at least, until the nutrient loading became sufficiently high to support dense epiphyte or macroalgal growth that inhibited the underlying macrophytes (e.g. Lee \& Olsen 1985, Dunton 1990). Zostera marina is more sensitive to pulsed nitrate enrichment than either co-inhabitant species, and likely would be replaced by $H$. wrightii or $R$. maritima in mixed beds impacted by progressive nitrate enrichment. For Z. marina, confronted by projected increases in nitrate loading within many coastal waters throughout the world (Miller 1992, World 
Resources Institute 1992), suitable area for colonization is projected to decrease. Collectively, our findings from 1990 and 1992 suggest that efforts to maintain or reestablish eelgrass in warm, poorly flushed eutrophic embayments and lagoons with seasonal anthropogenic nitrate loading will have low probability for long-term success.

Acknowledgments. Funding support for this research was provided by the Office of Sea Grant, NOAA, U.S. Dept of Commerce (Grant No. NA90AA-D-SG062) and the UNC Sea Grant College (Project No. R/MER-17), and by the AlbemarlePamlico Estuarine Study (NC Dept. of Environment, Health \& Natural Resources/U.S. EPA National Estuary Program) administered through the UNC Water Resources Research Institute, with additional support from the NC Agricultural Research Foundation (Project No. 06034), the NC Agricultural Research Service (Project No. 06188), and the Dept of Botany at NCSU. We extend special thanks to B. J. Copeland for his sustained enthusiasm and encouragement throughout our seagrass experiments. We are also grateful to $R$. Waite for his interest and support of this research, to F. A. Cross for graciousiy hosting us on the NMFS grounds, and to D. Moreau, R. Holman and E. Seneca for contributing their counsel and administrative support. In preparation for the 1992 experiments, sediment exchange was accomplished with help from P. Bates, J. Compton, M. Mallin and J. Rudek. T. Williams assisted in installation of more powerful chillers. The electrical system was redesigned with help from P. Bates, T. Brister, J. Compton, D. Lewis, C. F. Johnson and J. Russell. $M$. Fonseca is gratefully acknowledged for his assistance in transplanting efforts, as are J Russell and D. Lewis for their sustained effort in helping us to troubleshoot the experimental system. T Brister, V. Coleman, J. Compton, Sister G. Rentchez, M. McAuley, G. Morgan, L. Taggett and D. (Everitt) Tan also aided in transplanting and in marking plants. Sister G. Rentchis and T. Brister monitored the system daily in heroic efforts, with additional assistance from $V$. Coleman, M. Mallin, L. Peterson, L. Taggett and D. Tan. D. Kamykowski and R. Reed provided a Technicon II autoanalyzer for nitrate analysis. V. Clark, V. Coleman, J. Compton C. F. Johnson, M. Larsen, L. Taggett and D. Tan assisted in sample and data analyses. C. Brownie counseled us on statistics; and U. Blum, K. Bird, M. Mallin, M. McAulay and 2 anonymous colleagues kindly critiqued the manuscript.

\section{LITERATURE CITED}

Aber, J. D. (1992). Nitrogen cycling and nitrogen saturation in temperate forest ecosystems. TREE 7: 220-224

Alberts, E. E., Moldenhauer, W. C. (1981). Nitrogen and phosphorus transported by eroded soil aggregates. Soil Sci. Soc. Am. J. 45: 391-396

Batiuk, R. A., Orth, R. J., Moore, K. A., Dennison, W. C., Stevenson, J. C., Staver, L. W., Carter, V., Rybicki, N. B., Hickman, R. E., Kollar, S., Bieber, S., Heasly, P. (1992). Chesapeake Bay submerged aquatic vegetation habitat requirements and restoration targets: a technical synthesis. Report CBP/TRS83/92. Chesapeake Bay Program, U.S. Environmental Protection Agency, Annapolis

Bazzaz, F. A., Chiariello, N. R., Coley, P. D., Pitelka, L. F. (1987). Allocating resources to reproduction and defense. BioSci. 37: 58-67
Buchsbaum, R. N., Short, F. T., Cheney, D. P. (1990). Phenolicnitrogen interactions in eelgrass (Zostera marina L.): possible implications for disease resistance. Aquat. Bot. 37: $291-297$

Borum, J (1985). Development of epiphytic communities on eelgrass (Zostera marina) along a nutrient gradient in a Danish estuary. Mar. Biol. 87: 211-218

Burke, M. K., Dennison, W. C. (1993). Seasonal variation in the non-structural carbohydrate reserves of eelgrass Zostera marina $\mathrm{L}$. and the influence of shading (Abstract). In: The science \& management of coastal estuarine systems. Proceedings, 12th Bienniel International Estuarine Research Federation Conference, Hilton Head Island, SC, p. 15

Burkholder, J. M., Mason, K. M., Glasgow, H. B. Jr (1992). Water-column nitrate enrichment promotes decline of eelgrass Zostera marina L.: evidence from seasonal mesocosm experiments. Mar. Ecol. Prog. Ser. 61: 163-178

Burkholder, J. M., Sheath, R. G. (1985). Characteristics of softwater streams in Rhode Island. I. A comparative analysis of physical and chemical variables. Hydrobiologia 128: 97-108

Dawes, C. J., Kenworthy, W. J. (1990). Organic constituents. In: Phillips, R. C., McRoy, C. P. (eds.) Seagrass research methods. Monographs on Oceanographic Methodology, No. 9, Part I (Seagrasses). UNESCO, Paris, p. 87-98

Den Hartog, C. (1970). The sea-grasses of the world. North Holland, Amsterdam

Dennison, W. C. (1987). Effects of light on seagrass photosynthesis, growth and depth distribution. Aquat. Bot. 27: $15-26$

Dennison, W. C., Alberte, R. S. (1982). Photosynthetic responses of Zostera marina L. (eelgrass) to in situ manipulations of light intensity. Oecologia 55: 51-61

Dennison, W. C., Orth, R. J., Moore, K. A., Stevenson, J. C., Carter, V., Kollar, S., Bergstrom, P. W., Batiuk, R. A. (1993). Assessing water quality with submersed aquatic vegetation. BioSci. 43: 86-94

Dunton, K. H. (1990). Production ecology of Ruppia maritima L. s.l. and Halodule wrightii Aschers in two subtropical estuaries. J. exp. mar. Biol. Ecol. 143: 147-164

Ferguson, R. L., Rivera, J. A., Wood, L. L. (1988). Submerged aquatic vegetation in the Albemarle-Pamlico Estuarine System. Report No. 88-10 to the Albemarle-Pamlico Estuarine Study. North Carolina Department of Environment, Health \& Natural Resources, and the U.S. Environmental Protection Agency - National Estuary Program, Raleigh, NC

Fourqurean, J. W., Zieman, J. C., Macko, S. A., Hollibaugh, J. T., Moore, I (1993). Inferring ecosystem-scale patterns of nutrient availability and sources using regional distributions of C:N:P and ${ }^{15} \mathrm{~N}$ of seagrasses (Abstract). In: The science \& management of coastal estuarine systems. Proceedings, 12th Bienniel International Estuarine Research Federation Conference, Hilton Head Island, SC, p. 39

Froelich, P. N. (1988). Kinetic control of dissolved phosphate in natural rivers and estuaries: a primer on the phosphate buffer mechanism. Limnol. Oceanogr. 33: 649-668

Gill, J. L. (1978). Design and analysis of experiments in the animal and medical sciences, Vols. 1,2 and 3. lowa State University Press, Ames

Grobbelaär, J U. (1983). Availability to algae of $N$ and $P$ adsorbed on suspended solids in turbid waters of the Amazon River. Arch. Hydrobiol. 96: 301-316

Harlin, M. M., Thorne-Miller, B. (1981). Nutrient enrichment of seagrass beds in a Rhode Island coastal lagoon. Mar. Biol. 65: 221-229 
Jacobs, T. C., Gilliam, J. W. (1985). Riparian losses of nitrate from agricultural drainage waters. J. environ. Qual. 14: $472-478$

Jaworski, N. A., Groffman, P. M., Keller, A. A., Prager, J C. (1992). A watershed nitrogen and phosphorus balance: the upper Potomac River basin. Estuaries 15: 83-95

Kikuchi, T., Peres, J. M. (1977). Consumer ecology of seagrass beds. In: McRoy, C. P., Helfferich, C. (eds.) Seagrass ecosystems - a scientific perspective. Marcel Dekker, New York, p. 147-193

Lambers, H. (1985). Respiration in intact plant tissues: its regulation and dependence on environmental factors, metabolism and invaded organisms. In: Douce, R., Day, D. A (eds.) Encyclopedia of plant physiology, New series. Higher plant cell respiration. Springer-Verlag, Berlin, p. $418-474$

Lapointe, B. E., Clark, M.W. (1992). Nutrient inputs from the watershed and coastal eutrophication in the Florida Keys. Estuaries 15: 465-476

Lapointe, B. E., Tomasko, D. A. (1993). Trophic structuring of marine plant communities in the Florida Keys (Abstract). In: The science \& management of coastal estuarine systems. Proceedings, 12th Bienniel International Estuarine Research Federation Conference, Hilton Head Island, SC, p. 68

Lee, V., Olsen, S. (1985). Eutrophication and management initiatives for the control of nutrient inputs to Rhode Island coastal lagoons. Estuaries 8: 191-202

Levitt, J. (1980). Responses of plants to environmental stresses, Vol. II, Water, radiation, salt, and other stresses, 2nd edn. Academic Press, New York

Magnien, R. E., Summers, R. M., Sellner, K. G. (1992). External nutrient sources, internal nutrient pools, and phytoplankton production in Chesapeake Bay. Estuaries 15: 497-516

Maier, C. M. Pregnall, A. M. (1990). Increased macrophyte nitrate reductase activity as a consequence of groundwater input of nitrate through sandy beaches. Mar. Biol. 107: $263-271$

Marsh, J. A., Dennison, W. C., Alberte, R. S. (1986). Effects of temperature on photosynthesis and respiration in eelgrass (Zostera marina L.). J. exp. mar. Biol. Ecol. 101: 257-267

Mather, T. (1988). Scientists seek to protect endangered seagrasses. The News \& Observer, Raleigh, NC, 24 August

McRoy, C. P., McMillan, C. (1977). Production ecology and physiology of seagrasses. In: McRoy, C. P., Helfferich, C. (eds.) Seagrass ecosystems: a scientific perspective. Marcel Dekker, New York, p. 53-88

Miller, G. T. Jr (1992). Living in the environment, 7th edn. Wadsworth, Belmont, CA

Moffler, M. D., Durako, M. J. (1984). Axenic culture of Thalassia testudinum Banks ex König (Hydrocharitaceae). Am. J. Bot. 71. 1455-1460

Monbet, Y. (1992). Control of phytoplankton biomass in estuaries: a comparative analysis of microtidal and macrotidal estuaries. Estuaries 15: 563-571

Morris, I. (1974). Nitrogen assimilation and protein synthesis. In: Stewart, W. D. P. (ed.) Algal physiology and biochemistry. Botanical monographs, Vol. 10. University of California Press, Berkeley, p. 583-609

Muehlstein, L. K., Porter, D., Short, F. T (1991). Labyrinthula zosterae sp. nov., the causative agent of wasting disease of eelgrass, Zostera marina. Mycologia 83:180-191

Muenscher, W. C. (1964). Aquatic plants of the United States, 2nd printing. Vail-Ballou Press, Inc., Binghamton, NY

National Oceanic and Atmospheric Administration (NOAA) (1993). Local climatic data - weekly and monthly summaries for Beaufort, North Carolina, and water tempera- ture data for Beaufort Inlet. National Environmental Satellite, Data and Information Service, and National Marine Fisheries Service (W. Hettler), Beaufort, NC

Neckles, H. A. (1993). Relative effects of nutrient enrichment and grazing on epiphyte-macrophyte (Zostera marina L.) dynamics. Oecologia 93: 285-295

Nienhuis, P. H. (1992). Eutrophication, water management, and the functioning of Dutch estuaries and coastal lagoons. Estuaries 15: 538-548

North, W. J., Zimmerman, R. C. (1984). Influences of macronutrients and water temperatures on summertime survival of Macrocystis canopies. Hydrobiologia 116/117: 419-424

Orth, R. J., van Montfrans, J (1984). Epiphyte-seagrass relationships with an emphasis on the role of micrograzing: a review. Aquat. Bot. 18: 43-70

Orth, R. J., Simons, J., Capelli, J., Carter, V., Hindman, L., Hodges, S., Moore, K., Rybicki, N. (1986). Distribution of submerged aquatic vegetation in the Chesapeake Bay and tributaries - 1985. Final Report. United States Environmental Protection Agency, Washington, DC

Paerì, H. W., Mallin, M. A., Rudek, J., Bates, P. W. (1990). The potential for eutrophication and nuisance algal blooms in the Albemarle-Pamlico Estuary. Report No. 90-15 to the Albemarle-Pamlico Estuarine Study. North Carolina Department of Environment. Health \& Natural Resources and the U.S. Environmental Protection Agency - National Estuary Program, Raleigh, NC

Parsons, T R., Maita, Y., Lalli, C. M. (1985). A manual of chemical and biological methods for seawater analysis. Pergamon Press, New York

Paasche, E. (1988). Pelagic primary production in nearshore waters. In: Blackburn, T. H., Sorensen, J. (eds.) Nitrogen cycling in coastal marine environments. SCOPE 33. John Wiley \& Sons, New York, p. 33-57

Penhale, $P$. (1977). Macrophyte-epiphyte biomass and productivity in an eelgrass (Zostera marina L.) community. J. exp. mar. Biol. Ecol. 26: 211-224

Powell, G. V. N., Fourqurean, J. W., Kenworthy, W. J., Zieman, J. C. (1991). Bird colonies cause seagrass enrichment in a subtropical estuary: observational and experimental evidence. Estuar. coast. Shelf Sci. 32: 609-623

Pregnall, A. M., Smith, R. D., Alberte, R. S. (1987). Glutamine synthetase activity and free amino acid pools of eelgrass (Zostera marina L.) roots. J. exp. Mar. Biol. Ecol. 106: 211-228

Roth, N. C., Pregnall, A. M. (1988). Nitrate reductase activity in Zostera marina. Mar. Biol. 99: 457-463

Rudek, J., Paerl, H. W., Mallin, M. A., Bates, P. W. (1991). Seasonal and hydrological control of phytoplankton nutrient limitation in the lower Neuse River Estuary, North Carolina. Mar. Ecol. Prog. Ser. 75: 133-142

Salisbury, F. B., Ross, C. W. (1978). Plant physiology, 2nd edn Wadsworth, Belmont, CA

SAS Institute, Inc. (1987). SAS/STAT guide for personal computers, version 6 edn. SAS Institute, Inc., Cary, NC

Schneider, H. (1988). Pathological anatomy and mycology. In: Clark, G. (ed.) Staining procedures. Williams \& Wilkins, Baltimore, p. 367-373

Simon, N. S. (1989). Nitrogen cycling between sediment and shallow-water column in the transition zone of the Potomac River and Estuary. II. The role of wind-driven resuspension and absorbed ammonium. Estuar. coast. Shelf Sci. 28: $531-547$

Stanley, D. H. (1988). Historical trends in nutrient loading to the Neuse River Estuary, N.C. American Water Resources Association Symposium on Coastal Water Resources, Wilmington, NC, p. 155-164 
Stevenson, J. C. (1988). Comparative ecology of submersed grass beds in freshwater, estuarine, and marine environments. Limnol. Oceanogr. 33: 867-893

Thayer, G. W., Kenworthy, W. J, Fonseca, M. S. (1984). The ecology of eelgrass meadows of the Atlantic Coast: a community profile. United States Department of the Interior Fish and Wildlife Service Report \#FWS/OBS-84/02, Washington, DC

Thayer, G. W., Stuart, H. H., Kenworthy, W. J., Ustach, J. F., Hall, A. B. (1979). Habitat values of salt marshes, mangroves, and seagrasses for aquatic organisms. In: Greeson, P. E., Clark, J. R., Clark, J. E. (eds.) Wetland functions and values: the state of our understanding. American Water Resources Association, Minneapolis, p. 235-247

Turpin, D. H. (1991). Effects of inorganic $N$ availability on algal photosynthesis and carbon metabolism. J. Phycol. 27: $14-20$

Turpin, D. H., Elrifi, I. R., Birch, D. G., Weger, H. G., Holmes, J. J. (1988). Interactions between photosynthesis, respiration, and nitrogen assimilation in microalgae. Can. J. Bot. 66: $2083-2097$

Twilley, R. R., Kemp, W. M., Staver, K. W., Stevenson, J. C., Boynton, W. R. (1985). Nutrient enrichment of estuarine submersed vascular plant communities. 1. Algal growth and effects on production of plants and associated communities. Mar. Ecol. Prog. Ser. 23: 179-191

This article was presented by J. Lawrence, Tampa, Florida, USA
Valiela, I., Costa, J. E. (1988). Eutrophication of Buttermilk Bay, a Cape Cod coastal embayment: concentrations of nutrients and watershed nutrient budgets. Environ. Mgmt 12. $539-553$

Valiela, I., Costa, J. E., Foreman, K., Teal, J. M., Howes, B. Aubrey, D. (1990). Transport of groundwater-borne nutrients from watersheds and their effects on coastal waters. Biogeochemistry 10: 177-197

Valiela, I., Foreman, K., LaMontagne, M., Hersh, D., Costa, J. Peckol, P., DeMeo-Andreson, B., D'Avanzo, C., Babione, M., Sham, C.-H., Brawley, J., Lajtha, K. (1992). Couplings of watersheds and coastal waters: Sources and consequences of nutrient enrichment in Waquoit Bay, Massachusetts. Estuaries 15: 443-457

Williams, S. L., Ruckelshaus, M. H. (1993). Effects of nitrogen availability and herbivory on eelgrass (Zostera marina) and epiphytes. Ecology 74: 904-918

World Resources Institute (1992). Environmental almanac. Houghton Mifflin Co, Boston

Zieman, J. C., Wetzel, R. G. (1980). Productivity in seagrasses: methods and rates. In: Phillips, R. C., McRoy, C. P. (eds.) Handbook of seagrass biology: an ecosystem perspective. Garland Press, New York, p. 87-116

Zimmerman, R. C., Smith, R. D., Alberte, R. S. (1989). Thermal acclimation and whole-plant carbon balance in Zostera marina L. (eelgrass). J. exp. mar. Biol. Ecol. 130: 93-109

Manuscript first received: July 15, 1993

Revised version accepted: December 1, 1993 